Article

\title{
Design of Novel 4-Aminobenzofuroxans and Evaluation of Their Antimicrobial and Anticancer Activity
}

\author{
Elena Chugunova $1,2, *\left(\mathbb{D}\right.$, Almir Gazizov $1,2, * \mathbb{C}$, Marina Sazykina ${ }^{3}(\mathbb{D}$, Nurgali Akylbekov $4, * \mathbb{C}$, \\ Anastasiya Gildebrant ${ }^{3}{ }^{(1)}$, Ivan Sazykin ${ }^{3}$, Alexander Burilov ${ }^{1,2}$, Nurbol Appazov ${ }^{4,5}{ }^{(1)}$, \\ Shorena Karchava ${ }^{3}$, Maria Klimova ${ }^{3}$, Alexandra Voloshina $\left.{ }^{1}{ }^{(}\right)$, Anastasia Sapunova ${ }^{1}$, \\ Syumbelya Gumerova ${ }^{1} \oplus$, Ayrat Khamatgalimov ${ }^{1}\left(\mathbb{D}\right.$, Tatiana Gerasimova ${ }^{1}$, Alexey Dobrynin ${ }^{1}$, \\ Olga Gogoleva ${ }^{2}$ and Vladimir Gorshkov ${ }^{2}$ \\ 1 Arbuzov Institute of Organic and Physical Chemistry, FRC Kazan Scientific Center, Russian Academy of \\ Sciences, Kazan, Tatarstan 420088, Russia; burilov@iopc.ru (A.B.); sobaka-1968@mail.ru (A.V.); \\ microbi@iopc.ru (A.S.); syumbelya07@mail.ru (S.G.); ayrat_kh@iopc.ru (A.K.); tatyanagr@gmail.com (T.G.); \\ aldo@iopc.ru (A.D.) \\ 2 Laboratory of Plant Infectious Diseases, FRC Kazan Scientific Center of Russian Academy of Sciences, Kazan, \\ Tatarstan 420111, Russia; gogolewaoa@yandex.ru (O.G.); gvy84@mail.ru (V.G.) \\ 3 Southern Federal University, Rostov-on-Don 344090, Russia; submarinas@list.ru (M.S.); \\ siniamida@gmail.com (A.G.); zebra-sis@yandex.ru (I.S.); skarchava@sfedu.ru (S.K.); \\ mzhuravleva@sfedu.ru (M.K.) \\ 4 Laboratory of Engineering Profile "Physical and Chemical Methods of Analysis", Korkyt Ata Kyzylorda \\ University, Kyzylorda 120014, Kazakhstan; nurasar.82@mail.ru \\ 5 I. Zhakaev Kazakh Scientific Research Institute of Rice Growing, Kyzylorda 120008, Kazakhstan \\ * Correspondence: chugunova.e.a@gmail.com (E.C.); agazizov@iopc.ru (A.G.); nurgali_089@mail.ru (N.A.); \\ Tel.: +7-843-272-7324 (E.C.); +7-843-272-7324 (A.G.); +7-724-223-1041 (N.A.)
}

Received: 20 October 2020; Accepted: 29 October 2020; Published: 5 November 2020

\begin{abstract}
A series of novel 4-aminobenzofuroxan derivatives containing aromatic/aliphatic amines fragments was achieved via aromatic nucleophilic substitution reaction of 4,6-dichloro-5-nitrobenzofuroxan. The quantum chemistry calculations were performed to identify the factors affecting the regioselectivity of the reaction. The formation of 4-substituted isomer is favored both by its greater stability and the lower activation barrier. Antimicrobial activity of the obtained compounds has been evaluated and some of them were found to suppress effectively bacterial biofilm growth. Fungistatic activity of 4-aminobenzofuroxans were tested on two genetically distinct isolates of $M$. nivale. The effect of some benzofuroxan derivatives is likely to be more universal against different varieties of $M$. nivale compared with benzimidazole and carbendazim. Additionally, their anti-cancer activity in vitro has been tested. 4-aminofuroxans possessing aniline moiety showed a high selectivity towards MCF-7 and M-HeLa tumor cell lines. Moreover, they exhibit a significantly lower toxicity towards normal liver cells compared to Doxorubicin and Tamoxifen. Thus, benzofuroxans containing aromatic amines fragments in their structure are promising candidates for further development both as anti-cancer and anti-microbial agents.
\end{abstract}

Keywords: benzofuroxan; anti-cancer activity; apoptosis; bacterial biofilm; fungistatic activity; quantum chemical calculations

\section{Introduction}

Heterocyclic $N$-oxides hold a key position in the chemistry of organic compounds due to their usefulness as versatile synthetic intermediates and their biological importance. This motif has been 
successfully employed in a number of recent drug development investigations. There are numerous examples of antibacterial, anti-tuberculosis, antineoplastic, and other drugs derived from heterocyclic $\mathrm{N}$-oxides [1,2]. Among them, benzofuroxans represent the emerging class of compounds, which exhibit various biological activities [3-9]. Unsubstituted benzofuroxan and its chlorinated derivatives have been proposed as bactericides and fungicides for the treatment of seed peas, beans and potatoes, tetrabromotetrahydrobenzofuroxan has been proposed for agricultural use as an antifungal agent [10]. Notably, halogen-containing benzofuroxans are much more potent compared to their unsubstituted counterparts [11]. Additionally, the possibility of aromatic nucleophilic substitution of halogen atoms makes them promising candidates for further design of novel bioactive molecules.

Molecular modification is a rather promising strategy in the development of drug analogues with better bioavailability, higher biological activity, and less toxicity. Special attention is currently paid to the "hybrid" compound containing benzofuroxan and another biologically active subunit in one molecule $[3,12,13]$. Evaluation in vitro and in vivo of levels of prostaglandin E2 and thromboxane B2 decrease in the blood plasma samples of a compound obtained by binding of diclofenac and benzofuroxan fragments showed that after adding of benzofuroxan scaffold, this compound retains the pharmacological characteristics of Diclofenac, including anti-inflammatory activity, without the deleterious gastrointestinal effects which is normally present in the prototype [14]. The creation of novel "hybrid" compounds based on nitrobenzofuroxans is very important due to the high fungicidal and bactericidal activity inherent in their structure, the absence of toxicity and genotoxicity, as well as the possible presence of various protective biological effects.

In this work, we chose aromatic amines as the second fragment for "hybrid" compounds based on benzofuroxans. Aromatic amines are widely used as starting materials in pharmacology, fur and textile industries. They also serve as useful intermediates for the synthesis of numerous organic compounds $[15,16]$, including azo dyes, pigments, and as antioxidants in the manufacture of most rubber products [17]. However, most of them are highly toxic to living organisms, many of these aromatic compounds are carcinogenic and mutagenic for humans [18]. Notably, the literature data evidences that the introduction of a NO-donor benzofuroxan fragment into the molecule may result in its increased bioavailability and the pharmacological activity and reduced toxicity compared to the parent compound $[14,19,20]$. An additional advantage of using aromatic amines as the second fragment in the synthesis of "hybrid" compounds is their low cost and availability.

In order to show the importance of introducing namely fragments of aromatic amines into the structure of benzofuroxans, we also synthesized a number of compounds containing fragments of aliphatic amines and studied the anticancer and antimicrobial activities of both series of compounds. Future, using the example of the reaction 4,6-dichloro-5-nitrobenzofuroxan with aniline, we first explained the regioselectivity of the substitution of the chlorine atom in the 4 position with help of quantum chemical studies.

\section{Results and Discussion}

\subsection{Chemistry}

\subsubsection{Synthesis}

Key compounds were obtained via aromatic nucleophilic substitution reaction of 4,6-dichloro-5-nitrobenzofuroxan $\mathbf{1}$ using the aromatic amines $\mathbf{2 a - e}$ as nucleophiles (Scheme 1).

As in the previously illustrated examples [12,13], the obtained results indicate that the reactivity of two chlorine atoms in benzofuroxan 1 towards nucleophilic substitution differs significantly. The substitution occurred in the position 4 of the benzofuroxan 1 solely regardless of the reactants ratio, reaction time and the temperature. Thus, the reaction with all aromatic amines used afforded monosubstituted products 3a-f as the only products, even in the presence of great excess of the amine. 


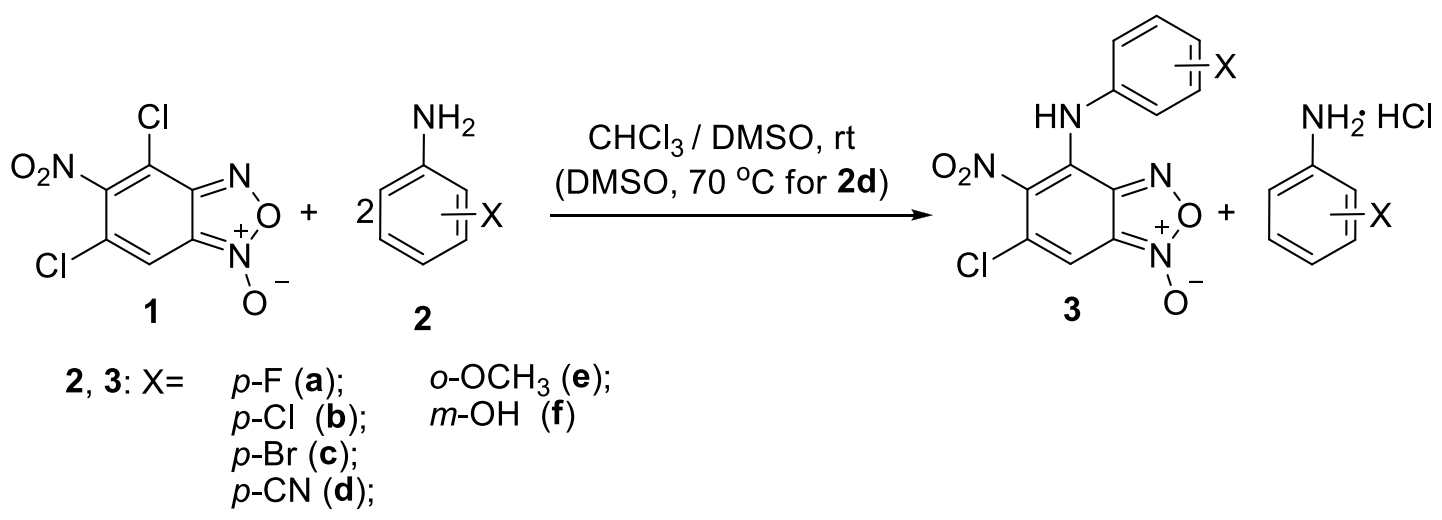

Scheme 1. Reaction of 4,6-dichloro-5-nitrobenzofuroxan 1 with aromatic amines.

It should be noted that the reaction time depends on the nature of the substituent in the anilines 2. In the case of the presence of electron-donating substituents the reaction finishes in $1-2 \mathrm{~h}$ at the room temperature. Vice versa, in the case of the presence of electron-withdrawing substituents the harsher conditions are required. For example, the reaction with $p$-aminobenzonitrile proceeds only upon heating the reagents at $70{ }^{\circ} \mathrm{C}$ in DMSO for $2 \mathrm{~h}$. These observations are in agreement with the lower nucleophilicity of anilines possessing electron-withdrawing substituents.

In addition, to further compare the biological activity of the two series of compounds we have synthesized a series of benzofuroxan derivatives containing fragments of aliphatic amines. The reaction proceeded similarly and resulted in 4-aminobenzofuroxans 5a-e (Scheme 2). The secondary aliphatic amines, both cyclic and acyclic, also behaved well providing compounds $\mathbf{5 f}, \mathbf{g}$, [acyclic: methylbenzylamine $\mathbf{4 f}$ and cyclic: pyrrolidine $\mathbf{4 g}$ ] (Scheme 2). Despite the greater nucleophilicity of aliphatic amines compared to anilines, no substitution occurred at the position 6 of benzofuroxan 1 .

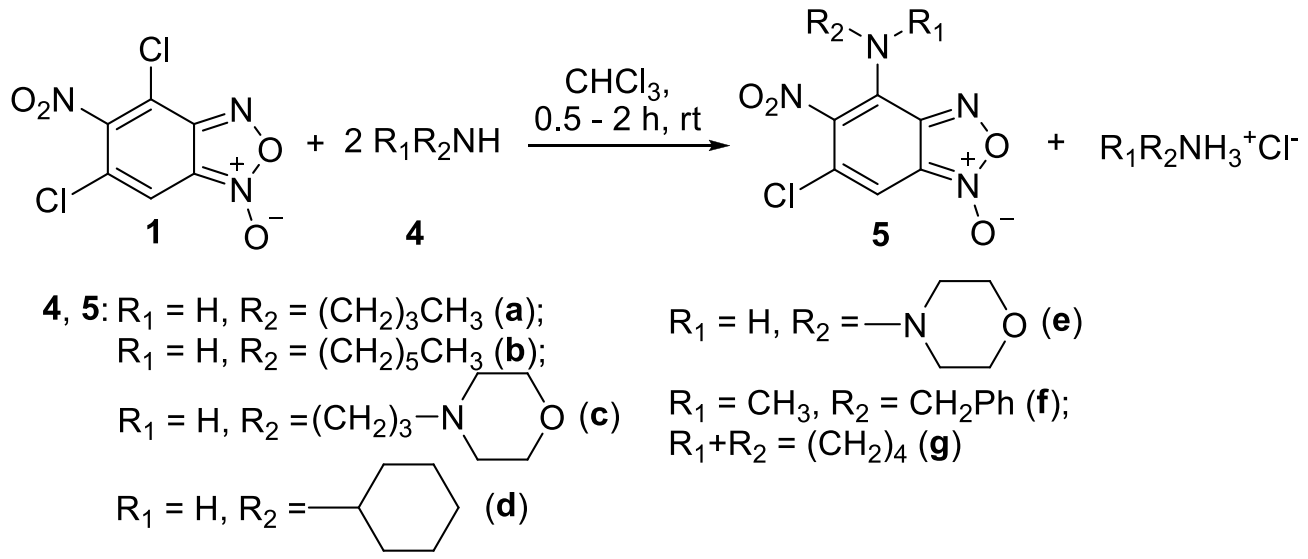

Scheme 2. Reaction of 4,6-dichloro-5-nitrobenzofuroxan $\mathbf{1}$ with aliphatic amines.

The key point in the elucidation of structures of obtained compounds 3a-f and 5a-g was the exact determination of their substitution site. This was achieved by $X$-ray experiments for the compounds 3a-d (see below, Figures 1-4). The substitution site of the compound $\mathbf{5 c}$ was determined through careful analysis of the ${ }^{13} \mathrm{C}$ NMR spectrum and its side-by-side comparison with the ${ }^{13} \mathrm{C}$ NMR spectra of compounds 3a-d. The substitution site of other compounds was determined similarly using previously described 6-chloro-4-((2-(dimethylamino)ethyl)amino)-5-nitrobenzofuroxan [21] as reference. 


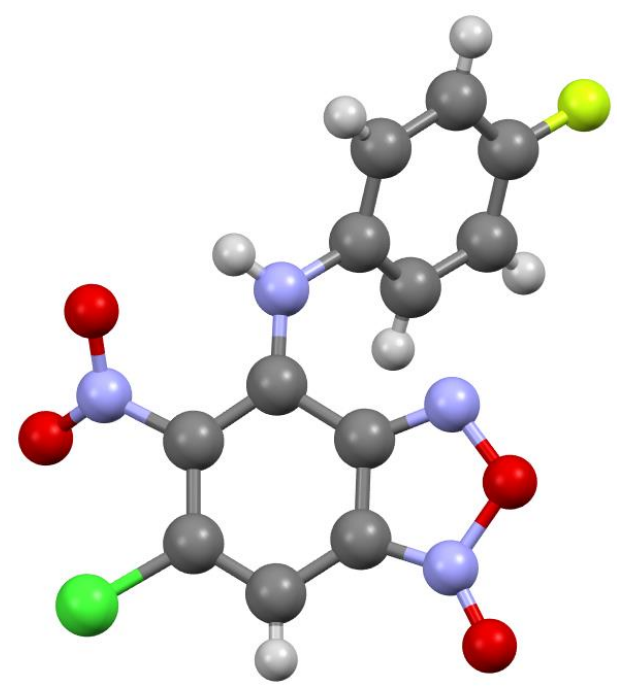

Figure 1. Molecular structure of compound 3a.

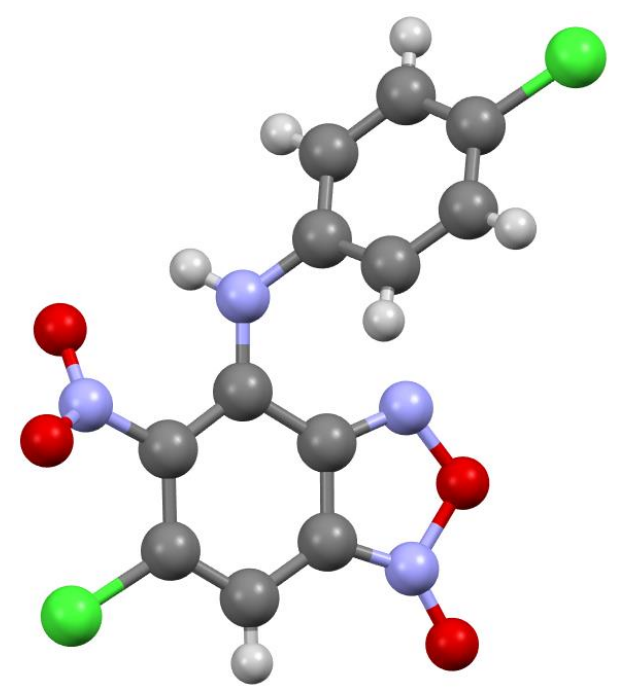

Figure 2. Molecular structure of compound 3b.

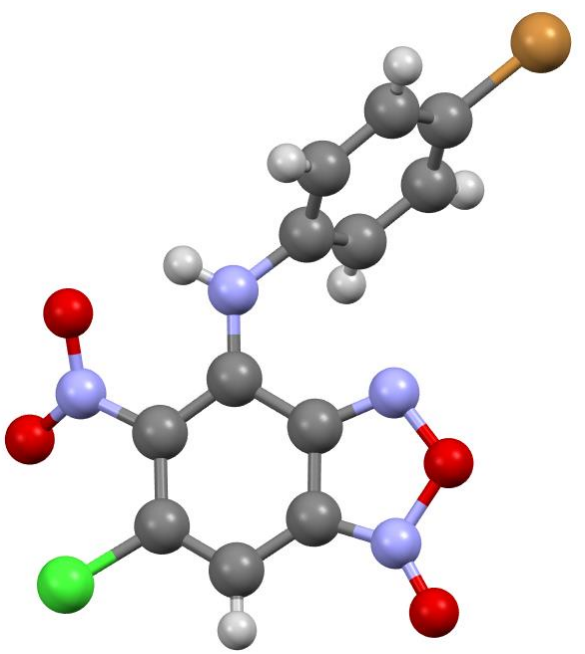

Figure 3. Molecular structure of compound 3c. 


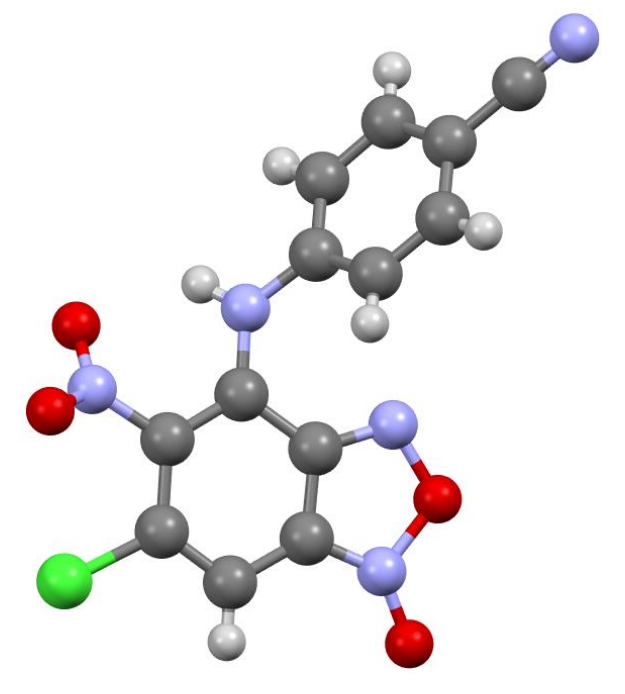

Figure 4. Molecular structure of compound 3d.

According to $\mathbf{X}$-ray data, compounds $\mathbf{3} \mathbf{a}, \mathbf{3} \mathbf{b}$ and $\mathbf{3} \mathbf{d}$ crystallize in the monoclinic space group $P 22_{1} /$. Compounds $\mathbf{3} \mathbf{a}$ and $\mathbf{3} \mathbf{b}$ are isostructural. Compound $\mathbf{3} \mathbf{c}$ crystallizes in the orthorhombic space group $\mathrm{Pbca}$ (Figures 1-4). Benzofuroxan's bicyclic fragments are planar, and substituted phenyl rings deviate from the plane of the bicycle. Moreover, substituted phenyls of compounds $3 \mathbf{a}$ and $3 \mathbf{c}$ deviate from the plane of the bicycle on one side (torsion angles 33.14 and $17.44^{\circ}$, respectively), but in compounds $\mathbf{3 b}$ and $\mathbf{3 d}$ deviates on the other side (torsion angles 32.25 and $35.71^{\circ}$, respectively). It should also be noted that in the same pairs of compounds $3 \mathbf{a} / \mathbf{3} \mathbf{c}$ and $\mathbf{3 b} / \mathbf{3 d}$, the nitro groups at aromatic rings deviate in different directions relative to the ring: in pair of the $3 \mathrm{a} / 3 \mathrm{c}$ the torsion angles are 16.9 and $27.63^{\circ}$, respectively, in the pair of $\mathbf{3 b} / \mathbf{3} \mathbf{d}$ the torsion angles are 37.97 and $43.39^{\circ}$, respectively.

\subsubsection{Quantum Chemical Calculations}

Although, aromatic nucleophilic substitution $\left(\mathrm{S}_{N} \mathrm{Ar}\right)$ reactions of 4,6-dichloro-5-nitrobenzofuroxan and different amines has been reported previously $[19,22]$ we have never tried to explain the reason for such an unusual phenomenon. The regioselectivity of this process becomes the major issue when a multiple functional groups are present in the molecule and more than one position can be substituted. The typical examples are reactions of 4,6-dinitro-5,7-dichlorobenzofuroxan, in which either of the chlorine atoms may be substituted [23] or the $S_{N}$ Ar reactions of polyhalogenated benzofused aza-heterocycles [24,25]. Similarly, the amination of pentafluoronitrobenzene leads to the mixture of $p$-, $o$ - and $p, 0-, O, O$-substituted products [26]. Thus, controlling the regioselectivity of the substitution in such substrates is a challenging task in the practically useful molecules design. Quantum chemistry methods have proved to be a valuable tool for the prediction or explanation of regioselectivity of $\mathrm{S}_{\mathrm{N}}$ Ar reactions. Various substrates have been studied, including polyhalogenated benzenes [27-29], perfluoronaphthlanes [30], polyhalogenoheterocycles [31-33] and their number continues to grow. Despite this, benzofuroxans received a little attention and this area still remains rather unexplored. To shed light on the peculiarities of interaction of 4,6-dichloro-5-nitrobenzofuroxan $\mathbf{1}$ with aniline (A) quantum-chemical study of this reaction has been carried out. Two possible ways have been considered: substitution of $\mathrm{Cl}$ atom (i) in $4(\mathbf{P a})$ and (ii) in $6(\mathbf{P b})$ positions with formation of Wheland-Meisenheimer zwitterionic intermediates (WM on Scheme 3). 


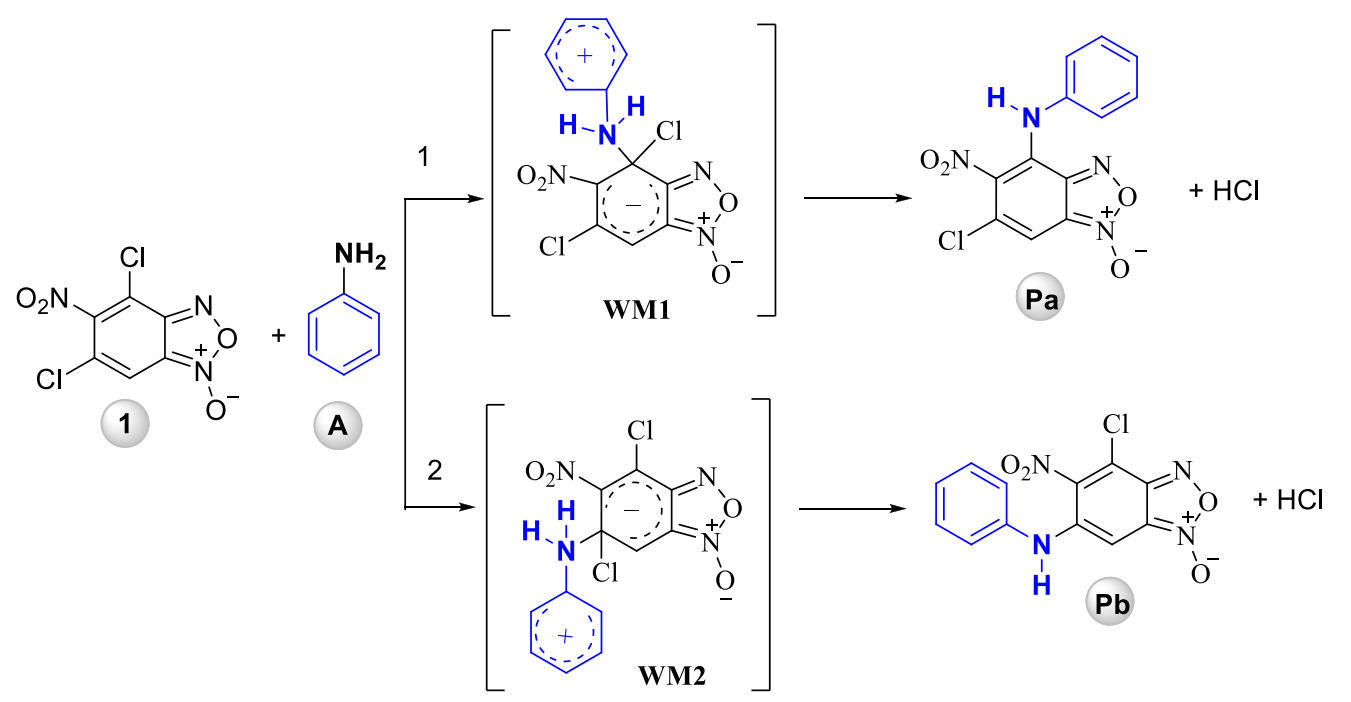

Scheme 3. Two possible ways for reaction of 4,6-dichloro-5-nitrobenzofuroxan $\mathbf{1}$ with aniline (A).

According to quantum chemical calculations results, the reaction of 5-nitro-4,6-dichlorobenzofuroxan $\mathbf{1}$ with aniline $\mathbf{A}$ is exothermic (thermal effect is 11.1 and $3.7 \mathrm{kcal} / \mathrm{mol}$, respectively, for the two expected reaction pathways, see Table 1) with Pa being thermodynamically more stable compared to $\mathbf{P b}$, higher HOMO-LUMO gap of $\mathbf{P a}$ suggests also its higher kinetical stability (Table 2).

Table 1. Relative energies ( $\Delta \mathrm{E}, \mathrm{kcal} / \mathrm{mol})$, enthalpies $(\Delta \mathrm{H}, \mathrm{kcal} / \mathrm{mol})$ and $\mathrm{Gibbs}$ energies $(\Delta \mathrm{G}, \mathrm{kcal} / \mathrm{mol})$ of products $\mathbf{P a}$ and $\mathbf{P b}$ with $\mathrm{HCl}$ compared to initial reagents 4,6-dichloro-5-nitrobenzofuroxan $\mathbf{1}$ with aniline A (Scheme 3).

\begin{tabular}{cccc}
\hline Reaction Products & $\Delta \mathrm{E}$ & $\Delta \mathbf{H}$ & $\Delta \mathrm{G}$ \\
\hline $\mathbf{P a}+\mathbf{H C l}$ & 9.91 & 11.13 & 8.21 \\
$\mathbf{P b}+\mathbf{H C l}$ & 2.32 & 3.70 & 1.37 \\
\hline
\end{tabular}

Table 2. Relative energies ( $\Delta \mathrm{E}, \mathrm{kcal} / \mathrm{mol})$, enthalpies $(\Delta \mathrm{H}, \mathrm{kcal} / \mathrm{mol})$, Gibbs free energies $(\Delta \mathrm{G}, \mathrm{kcal} / \mathrm{mol})$ and Highest occupied molecular orbital-lowest unoccupied molecular orbital (HOMO-LUMO) gaps (eV) for products $\mathbf{P a}$ and $\mathbf{P b}$, reagents, pre-reaction complexes and transition states of the reaction of 4,6-dichloro-5-nitrobenzofuroxan $\mathbf{1}$ with aniline $\mathbf{A}$.

\begin{tabular}{ccccc}
\hline & $\boldsymbol{\Delta E}$ & $\boldsymbol{\Delta H}$ & $\boldsymbol{\Delta G}$ & HOMO-LUMO \\
\hline $\mathbf{1}_{\mathbf{+} \mathbf{A}} \mathbf{*}$ & 0.00 & 0.00 & 0.00 & - \\
$\mathbf{R}_{(\mathbf{1}+\mathbf{A}) \mathbf{a}}$ & -3.41 & -2.09 & 5.69 & - \\
$\mathbf{R}_{(\mathbf{1}+\mathbf{A})} \mathbf{b}$ & -3.20 & -1.90 & 6.46 & - \\
$\mathbf{W M 1}$ & 15.02 & 16.28 & 30.80 & 3.10 \\
$\mathbf{W M 2}$ & 29.61 & 30.75 & 44.41 & 2.13 \\
$\mathbf{P a}+\mathbf{H C l}$ & -9.91 & -11.13 & -8.21 & 2.99 \\
$\mathbf{P b}+\mathbf{H C l}$ & -2.32 & -3.70 & -1.37 & 2.86 \\
\hline
\end{tabular}

Thus, quantum chemical modeling shows that the formation of Pa (6-chloro-5-nitro-4-(phenylamino)benzofuroxan) is preferable compared to $\mathbf{P b}$ (4-chloro-5-nitro-6-(phenylamino)benzofuroxan) that is proved by thermodynamic stability of the reaction product, thermal effect of the reaction and lower activation barrier of $\mathbf{P a}$ (6-chloro-5-nitro-4-(phenylamino)benzofuroxan) formation (for details, see Supplementary Materials, Figures S1-S3, Table S1). Thus, the quantum chemistry calculations support fully the experimental data obtained earlier and in this investigation and evidences the greater reactivity of the chlorine atom in the 4th position of the 4,6-dichloro-5-nitrobenzofuroxan 1. 


\subsection{Biological Studies}

\subsubsection{Anti-Biofilm Activity of Benzofuroxan Derivatives}

Currently the screening of bioactive compounds involves a large number of analysis assays that allow assessing the potential of biological extracts or molecules. The assays can be performed at the whole animal, cell-based or molecular levels [34].

Anyway, the search for substances which may be used as therapeutics for diseases associated with bacteria, is of great interest. A large number of laboratories and companies around the world are occupied with the problem of search of the medicines possessing complex medical action, and, in particular, antibacterial activities [35-39].

Microbial infections have become an important clinical threat, with significant associated morbidity and mortality, which is mainly due to the development of microbial resistance to the existing antimicrobial agents. Therefore, methods for antimicrobial susceptibility testing and discovery of novel antimicrobial agents have been extensively used. All of the most important groups of antibiotics are in danger of losing their efficacy because of the increase in microbial resistance. For this reason, the discovery of new antimicrobials is one of the main objectives of medicine nowadays. One of the main strategies of bacteria survival in the organisms of the infected owners is formation of biofilm communities of microorganisms. This way of bacteria existence creates big problems in medical practice. In this regard, the search for and studying of substances which can suppress formation of biofilms and kill bacteria in biofilms is an extremely important and relevant problem of antimicrobial therapy.

Considering the abovesaid, it was of interest to define anti-biofilm activity in our substances.

The data obtained during the study of biofilm formation degree by the strain Vibrio aquamarinus DSM 26054 in the presence of the studied substances are shown in Table 3 (see Supplementary Materials, Figures S4-S14 for additional data).

Table 3. Biofilm formation (\%) by V. aquamarinus DSM 26054 in the presence of benzofuroxan derivatives in reference to control (control $=100 \%)$.

\begin{tabular}{|c|c|c|c|c|c|c|}
\hline \multirow{3}{*}{ Compound } & \multicolumn{6}{|c|}{ Biofilm Formation, \% } \\
\hline & \multicolumn{6}{|c|}{ Compound Concentration, $\mathrm{M}$} \\
\hline & $1 \times 10^{-9}$ & $1 \times 10^{-8}$ & $1 \times 10^{-7}$ & $1 \times 10^{-6}$ & $1 \times 10^{-5}$ & $1 \times 10^{-4}$ \\
\hline $3 a$ & 104.09 & 81.39 & $51.29 *$ & $104.19 *$ & 116.74 & 108.56 * \\
\hline $3 b$ & $29.56^{*}$ & $18.75 *$ & $49.17 *$ & 98.92 & $46.33 *$ & $5.78 *$ \\
\hline $3 c$ & 83.88 & $22.91 *$ & $67.33 *$ & 91.23 & $121.82 *$ & $6.23 *$ \\
\hline $3 d$ & $15.18^{*}$ & $11.69 *$ & $57.03 *$ & 100.31 & $63.01 *$ & 118.72 * \\
\hline $3 e$ & 85.02 & 85.82 & $41.01 *$ & 96.34 & $65.93 *$ & $94.48 *$ \\
\hline $3 f * *$ & 66.58 & $9.31 *$ & 11.34 * & 43.56 * & 96.57 & 98.97 \\
\hline $5 b$ & 88.50 & $25.54 *$ & 37.51 * & 88.43 * & 92.32 & 100.88 \\
\hline $5 e$ & $26.21 *$ & $21.15 *$ & $70.11 *$ & 96.38 & 116.36 & 110.85 * \\
\hline $5 f$ & $25.67 *$ & $26.88 *$ & $63.58 *$ & 96.08 & 96.24 & 103.47 \\
\hline $5 g$ & $45.78 *$ & $22.40 *$ & $27.37 *$ & $79.81 *$ & 108.84 & 107.18 \\
\hline Azithromycin & 103.42 & 102.43 & 99.39 & 103.80 & 81.50 * & 103.42 \\
\hline
\end{tabular}

\footnotetext{
* Differences compared to the control samples are statistically significant, $t$ criterion, $p<0.05$; the solutions of appropriate solvent in ethanol with the same concentration were used as control in experiments with benzofuroxans; six replicates were done for each treatment and control; ${ }^{* *}$ Data for compound $3 \mathbf{f}$ were first published in [40].
}

Substances 3a, 3c, 3d, 5e are able to both stimulate and inhibit biofilms formation by the strain $V$. aquamarinus DSM 26054 depending on the concentration. Similar effects were shown in our earlier works for various 1-[(2-aminoethyl)sulfonyl]-2-arylpyrrolidines, 2-(pyrazolyl)pyrrolidines and pyrrolidine-1-carboxamides [40-42]. Such an oppositely directed dose-dependent effect is known for various groups of substances, including antibiotics, and is described in the literature as hormesis [43-45]. Such effects are of interest for further studies, but due to this substance 3a, 3c, 3d, 5e 
are not recommended to be used as pharmaceuticals capable of inhibiting the biofilm development of vibrios.

Substances $\mathbf{3 b}, \mathbf{3 e}, \mathbf{3 f}, \mathbf{5} \mathbf{b}, \mathbf{5 f}, \mathbf{5} \mathbf{g}$ had an inhibitory effect on biofilm formation in a number of studied concentrations. Biofilm formation compared to control ranged from $5.78 \%$ to $94.48 \%$. The maximum inhibitory effect was exerted by $3 \mathbf{b}$ substance at the concentration of $10^{-4} \mathrm{M}$ (biofilm formation was $5.78 \%$ ). At the concentration of $10^{-5} \mathrm{M}$, the inhibitory effect was recorded when exposed to substances $\mathbf{3} \mathbf{b}$ and $\mathbf{3 e}$ - the intensity of biofilm formation compared to the control was $46.33 \%$ and $65.93 \%$, respectively. At the concentration of $10^{-6} \mathrm{M}$, substances $\mathbf{3 f}, \mathbf{5 b}$ and $\mathbf{5 g}$ demonstrated the ability to suppress the development of biofilms (the intensity of biofilm formation was $43.56,88.43 \%$ and $79.81 \%$, respectively). Substances $\mathbf{3 b}, \mathbf{3 e}, \mathbf{3} \mathbf{f}, \mathbf{5 b}, \mathbf{5 f}, \mathbf{5} \mathbf{g}$ showed anti-biofilm activity at the concentration of $10^{-7} \mathrm{M}$; the intensity of biofilm formation varied from 11.34 (3f) to $63.58 \%$ (5f). At the concentration of $10^{-8} \mathrm{M}$, substances $\mathbf{3 b}, \mathbf{3} \mathbf{f}, \mathbf{5} \mathbf{b}, \mathbf{5 f}$, and $\mathbf{5 g}$ displayed a pronounced inhibitory effect-the intensity biofilms of biofilm formation ranged from $9.31 \%$ (3f) to $26.88 \%(5 \mathrm{~g})$. At the concentration of $10^{-9} \mathrm{M}$, substances $\mathbf{3 b} \mathbf{b} \mathbf{5}$ and $\mathbf{5 g}$ effectively inhibited the formation of (the intensity of biofilm formation compared to the control was $29.56 \%, 25.67 \%$, and $45.78 \%$, respectively).

The tested compounds were also compared with a standard antibiotic Azithromycin (see Supplementary Materials for additional data). Azithromycin exhibited an insignificant biofilm suppression at a high concentration. Azithromycin suppressed the intensity of biofilm formation by V. aquamarinus DSM 26054 at the concentration of $10^{-5} \mathrm{M}$ (Figure S14). The optical density was $81.5 \%$ of the control values.

Thus, 5 substances capable of suppressing the vibrios biofilm formation in low concentrations $\left(10^{-9}-10^{-7} \mathrm{M}\right)-\mathbf{3 b}, \mathbf{3 e}, \mathbf{3 f}, \mathbf{5 b}, \mathbf{5 f}, \mathbf{5} \mathbf{g}$ were isolated.

\subsubsection{Fungistatic Activity of Benzofuroxans}

Snow mold is a severe plant disease caused by psychrophilic and psichrotolerant fungi and fungi-like organisms [46]. These fungi damage mostly winter cereals as well as forage and turf grasses during autumn to spring period resulting in high crop losses. Microdochium nivale (Fr.) Samuels and Hallet is the most common reason for biotic winter crop damage [47-49]. Being a psychrotolerant fungus, $M$. nivale is able to cause disease not only at cool period, but also during the whole growing season leading to both snow mold as well as fusariosis-resemble diseases such as seedling blight, foot rot, leaf blight, and head blight [46]. M. nivale is a genetically diverse species represented by multiple genotypes $[50,51]$. The prevention of snow mold accounts for almost $50 \%$ of the yearly fungicide use on turfgrass in Canada [52]. Despite that, $M$. nivale remains common and serious pathogen, which is in particular related to the formation of fungicide-resistance [53].

In our study, two genetically distinct isolates of M. nivale from the culture collection of FRC Kazan Scientific Center of RAS were used to test fungistatic activity of benzofuroxans. The parent compound (4,6-dichloro-5-nitrobenzofuroxan) was not effective against the analyzed isolates of $M$. nivale: it caused the reduction in fungal growth only during first three days of incubation. All of the tested benzofuroxan derivatives were more efficient than the parental compound (Figure 5). The most effective ones were the derivatives $3 \mathbf{b}, 3 \mathbf{c}$. They caused more than $40 \%$ and $25 \%$ of growth inhibition on the fifth and sixth day of incubation, respectively, on both isolates. The least effective one was the derivative $\mathbf{5 f}$ : it caused less than $20 \%$ and $10 \%$ of growth inhibition on the fifth and sixth day of incubation, respectively, on both isolates. Interestingly, two derivatives displayed isolate-specific fungistatic activity. The derivative 5 a was one of the most effective against isolate 1 , but on isolate 21 , it caused only $10 \%$ of inhibition on the fifth day of incubation and did not cause any inhibition by the sixth day of incubation. Contrarily, the derivative $3 \mathbf{e}$ caused one of the most pronounced inhibitory effects on isolate 21 but was inefficient against isolate 1. 

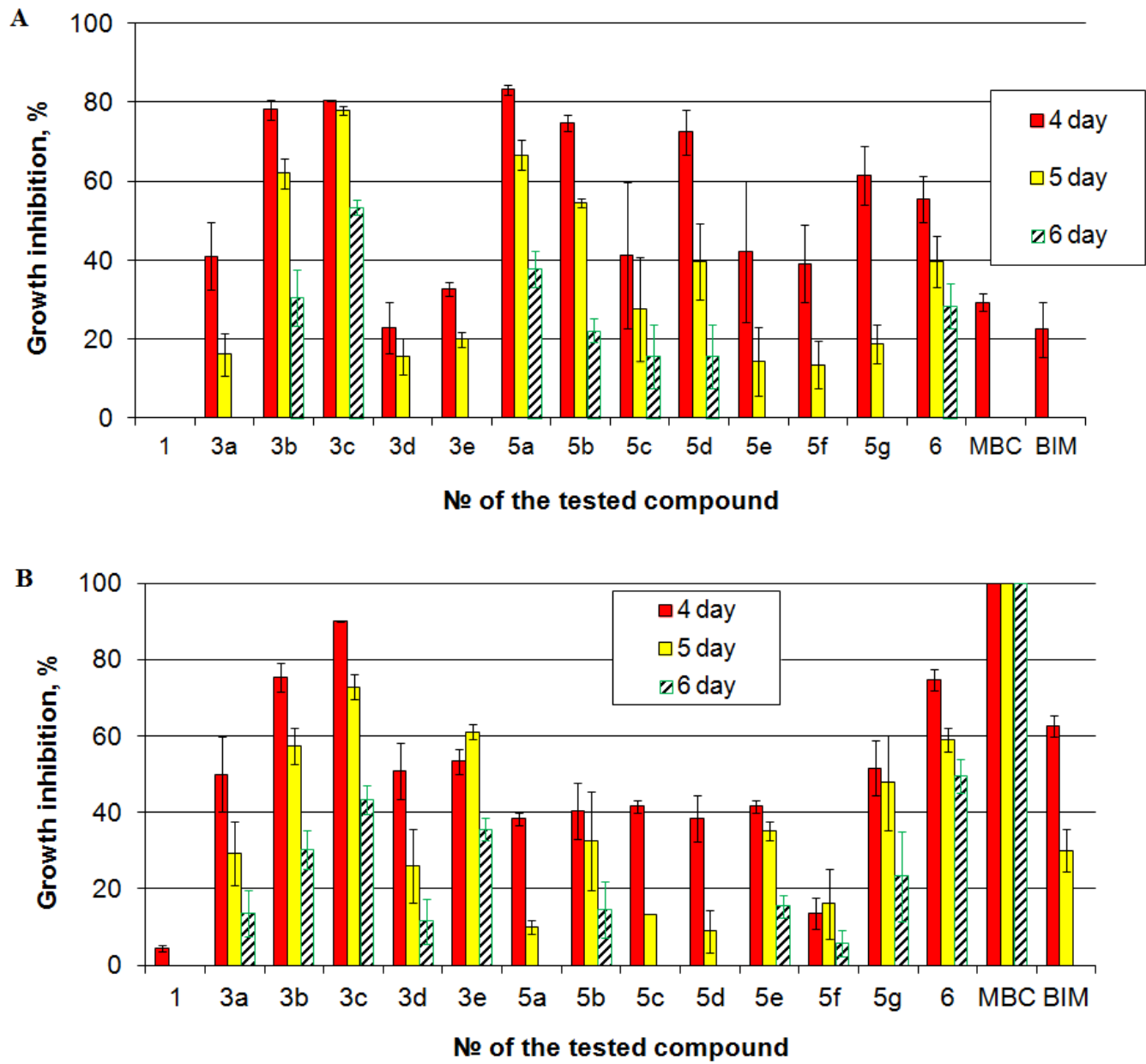

Figure 5. Fungistatic activity of the tested compounds determined on two isolates of Microdochium nivale: (A) isolate 1; (B) isolate 21. The presented values are averages \pm standard error of at least three biological replicates. Red columns -4 day of incubation, yellow columns -5 day of incubation, hatched columns -6 day of incubation.

To compare the effects of benzofuroxans with that of the traditionally applied fungicides, benzimidazole (BIM) and carbendazim (methyl-2-benzimidazole carbamate, MBC) were used. Both carbendazim and benzimidazole had null inhibitory effect on isolate 1 by the fifth day of incubation (Figure 5). Herewith, on isolate 21, carbendazim caused $100 \%$ growth inhibitory effect till the sixth day of incubation. The effect of benzimidazole was lower than that of benzofuroxan derivatives $\mathbf{3 b}, \mathbf{3}$. Thus, although carbendazim is able to cause strong fungistatic effect against one isolates, there are isolates that display pronounced resistance to this compound. This is consistent with widely shown carbendazim-resistance of plant pathogenic [54-56]. In turn, the effect of some benzofuroxan derivatives $(\mathbf{3 b}, \mathbf{3} \mathbf{c})$ is likely to be more universal against different varieties of $M$. nivale.

For the comparison purposes we have also obtained the compound $\mathbf{6}$ as a mixture of tautomers (Figure 6) by the reaction of 7-chloro-4,6-dinitrobenzofuroxan with 4-isopropylaniline (see experimental part for the synthesis details). Its activity turned out to be comparable to that of lead compounds. 


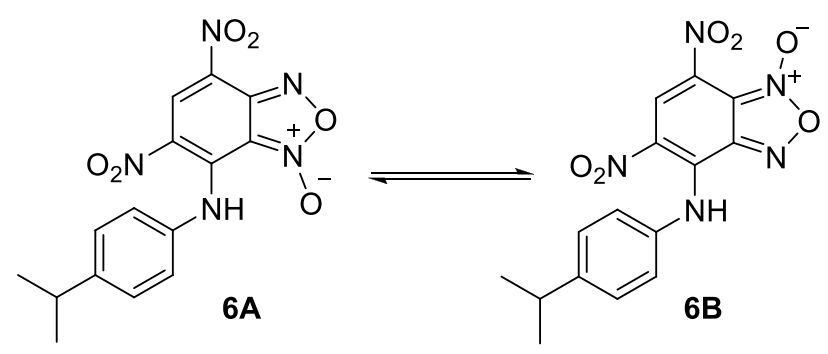

Figure 6. Structure of the tautomers of compound 6.

\subsubsection{Cytotoxicity of Test Compounds Toward Cancer and Normal Human Cell Lines}

We have previously shown that compounds containing benzofuroxan fragments exhibit cytotoxic activity against some cancer cell lines [40]. In this regard, a series of new amino-containing benzofuroxan derivatives was tested for cytotoxicity against normal (Chang liver-normal human liver cells) and human cancer cell lines (M-HeLa-epithelioid carcinoma of the cervix; MCF-7-breast adenocarcinoma cells human; PANC-1-human pancreatic cancer cell line, glioblastoma cell line (T98G)).

The compounds tested showed high activity against cancer cell lines and low cytotoxicity against normal cells. The most significant results were obtained in the case of compounds $3 \mathbf{c}$ and $3 \mathbf{f}$ demonstrating selective cytotoxicity against the line of cervical carcinoma cells (M-HeLa) and breast adenocarcinoma cells human (MCF-7), which was comparable to the reference drug Doxorubicin and significantly exceeded Tamoxifen with an anti-cancer effect. Compounds $\mathbf{3 d}$ and $\mathbf{3 b}$ proved to be the most active against glioblastoma cell line (T98G). The $\mathrm{IC}_{50}$ values for these compounds were 14.7 and $12.7 \mu \mathrm{M}$, respectively. The selectivity of compounds for cancer cells is an important criterion for assessing the cytotoxic effect. For this, the selectivity index (SI) was calculated as the ratio between the $\mathrm{IC}_{50}$ value for normal cells and the $\mathrm{IC}_{50}$ value for cancer cells. The values $\mathrm{IC}_{50}$ and $\mathrm{SI}$ for the tested compounds are shown in Table 4.

The compounds with SI $\geq 3$ are usually highly selective [57]. In this regard, it can be considered that compounds $\mathbf{3 f}$ and $\mathbf{3 c}$ are highly selective towards (MCF-7) and M-HeLa cell lines. The SI values for these lines were from 4.0 to 12.8. Doxorubicin and Tamoxifen reference drugs were far inferior to the leading compounds in selectivity.

The tested compounds were less active against human pancreatic cancer cell line (PANC-1). However, it is important to note that in relation to the line of normal liver cells, all tested compounds showed significantly lower toxicity compared to Doxorubicin and Tamoxifen.

\subsubsection{Induction of Apoptotic Effects by Test Compounds}

Using the method of flow cytometry, studies were carried out that made it possible to establish whether the cytotoxic effect of the tested compounds is associated with the induction of apoptosis in cancer cells using the example of compounds of leaders $3 \mathrm{c}$ and $\mathbf{3 f}$.

As shown in Figure 7, after $24 \mathrm{~h}$ of treatment, apoptotic effects were observed for both compounds in M-HeLa cells. At a concentration similar to the $\mathrm{IC}_{50}$ value, compound $3 \mathrm{c}$ caused early and late apoptosis in $6.67 \%$ and $8.63 \%$ of M-HeLa cells, respectively, and compound $3 \mathrm{f}$, under the same conditions, caused early and late apoptosis in $14.46 \%$ and $12.79 \%$ of M-HeLa cells, respectively. It can be seen that compound $3 \mathrm{f}$ at a concentration similar to the $\mathrm{IC}_{50}$ value induces apoptosis more actively than $3 \mathrm{c}$. The number of apoptotic cells at the stage of early apoptosis after treatment with $3 \mathrm{f}$ increased by almost three times. When treated with compound $\mathbf{3 c}$, apoptosis in the early stage does not develop so actively (the number of apoptotic cells changes insignificantly compared to the control). With an increase in the concentration of compounds $3 \mathrm{c}$ and $\mathbf{3 f}$ to $10 \mu \mathrm{M}$ and $15 \mu \mathrm{M}$, respectively, the number of cells in early and late apoptosis is approximately the same. The results suggest that the cytotoxic effects induced by compounds $3 \mathbf{c}$ and $\mathbf{3 f}$ in M-HeLa cancer cells are due to an apoptotic pathway. 
Table 4. In vitro cytotoxic effects $\left(\mathrm{IC}_{50} \mu \mathrm{M}\right)$ and selectivity index values (SI) of Test compound ${ }^{\mathrm{a}}$.

\begin{tabular}{|c|c|c|c|c|c|c|c|c|c|}
\hline \multirow{3}{*}{ Test Compound } & \multicolumn{8}{|c|}{ Cancer Cell Lines } & \multirow{3}{*}{$\begin{array}{c}\text { Normal Cell Lines } \\
\text { Chang Liver }\end{array}$} \\
\hline & \multicolumn{2}{|c|}{ M-HeLa } & \multicolumn{2}{|c|}{$\mathrm{MCF}_{7}$} & \multicolumn{2}{|c|}{ PANC-1 } & \multicolumn{2}{|c|}{ T98G } & \\
\hline & $\mathrm{IC}_{50}$ & SI & $\mathrm{IC}_{50}$ & SI & $\mathrm{IC}_{50}$ & SI & $\mathrm{IC}_{50}$ & SI & \\
\hline $3 a$ & $45.9 \pm 3.7$ & 2.0 & $>100$ & n.s. & $>100$ & n.s & $28.3 \pm 2.3$ & 3.3 & $93.8 \pm 8.3$ \\
\hline $3 b$ & $60.6 \pm 4.7$ & 1.0 & $69.2 \pm 5.7$ & n.s. & $82.7 \pm 7.3$ & n.s & $12.7 \pm 1.1$ & 5.0 & $62.7 \pm 5.5$ \\
\hline $3 c$ & $4.8 \pm 0.4$ & 12.8 & $3.7 \pm 0.2$ & 16.6 & $59.2 \pm 4.6$ & 1.0 & $20.4 \pm 1.7$ & 3 & $61.3 \pm 5.1$ \\
\hline $3 d$ & $16.6 \pm 1.4$ & $>6$ & $67.9 \pm 5.7$ & $>1.5$ & $61.3 \pm 5.1$ & $>1.6$ & $14.7 \pm 1.2$ & $>6.8$ & $>100$ \\
\hline $3 e$ & $62.7 \pm 5.4$ & 1.0 & $79.5 \pm 6.4$ & n.s. & $50.0 \pm 4.1$ & 1.3 & $21.5 \pm 1.8$ & 3.0 & $62.7 \pm 5.6$ \\
\hline $3 f$ & $16.0 \pm 1.3$ & 4.0 & $8.1 \pm 0.7$ & 8.0 & $>100$ & n.s. & $59.8 \pm 4.8$ & 1.1 & $64.4 \pm 5.7$ \\
\hline $5 a$ & $56.5 \pm 4.5$ & 1.8 & $>100$ & n.s. & $>100$ & n.s. & $22.7 \pm 1.9$ & 4.4 & 100 \\
\hline $5 b$ & $60.8 \pm 4.8$ & $>1.6$ & $>100$ & n.s. & $50.0 \pm 3.9$ & $>2$ & $65.0 \pm 5.8$ & $>1.5$ & $>100$ \\
\hline $5 c$ & $49.3 \pm 3.9$ & $>2$ & $>100$ & n.s. & $38 \pm 2.9$ & $>2.6$ & $>100$ & n.s. & $>100$ \\
\hline $5 d$ & $61.0 \pm 5.2$ & 1.1 & $79.1 \pm 6.2$ & n.s. & $>100$ & n.s. & $31.6 \pm 2.5$ & 2.1 & $67.1 \pm 5.7$ \\
\hline $5 e$ & $61.6 \pm 5.2$ & 1.1 & $>100$ & n.s. & $>100$ & n.s. & $57.1 \pm 4.3$ & 1.1 & $65.2 \pm 5.8$ \\
\hline $5 f$ & $62.2 \pm 5.6$ & $>1.6$ & $>100$ & n.s. & $>100$ & n.s. & $>100$ & n.s. & $>100$ \\
\hline $5 g$ & $>100$ & n.s. & $>100$ & n.s. & $>100$ & n.s. & $>100$ & n.s. & $>100$ \\
\hline Doxorubicin & $3.0 \pm 0.1$ & 1.0 & $3.0 \pm 0.2$ & 1.0 & $3.3 \pm 0.1$ & 1.0 & $6.8 \pm 0.5$ & n.s. & $3.0 \pm 0.2$ \\
\hline Tamoxifen & $28 \pm 2.5$ & 1.5 & $25 \pm 2.2$ & 1.7 & & & - & & $42.1 \pm 3.5$ \\
\hline
\end{tabular}

${ }^{a}$ The experiments were repeated for three times. The results are expressed as the mean \pm standard deviation (SD); n.s. - no selectivity. 

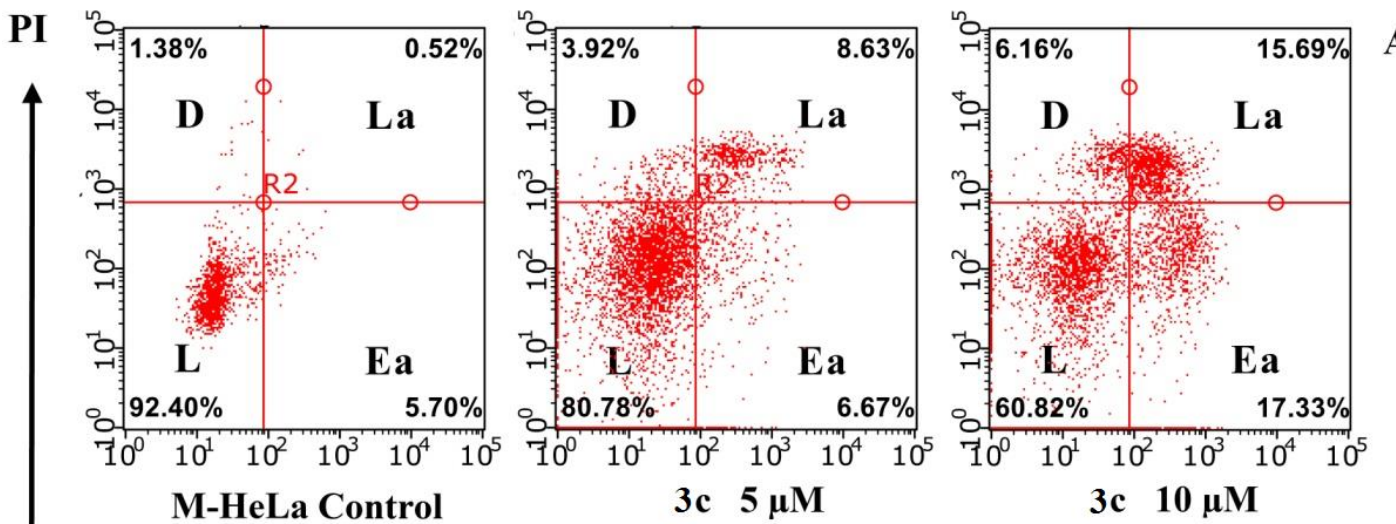

A

M-HeLa Control
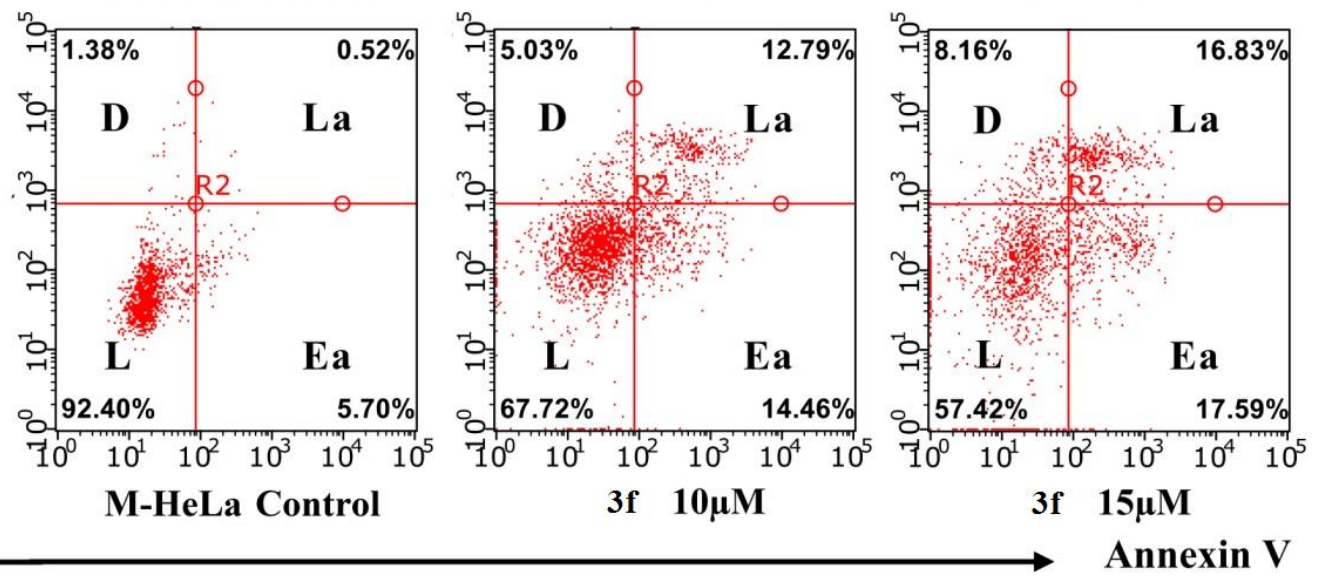

Compound 3e

Compound 3f

B

口Early apoptosis

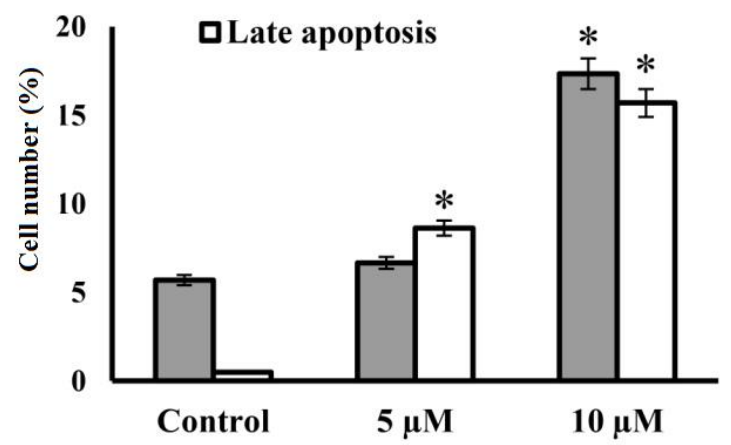

口Early apoptosis

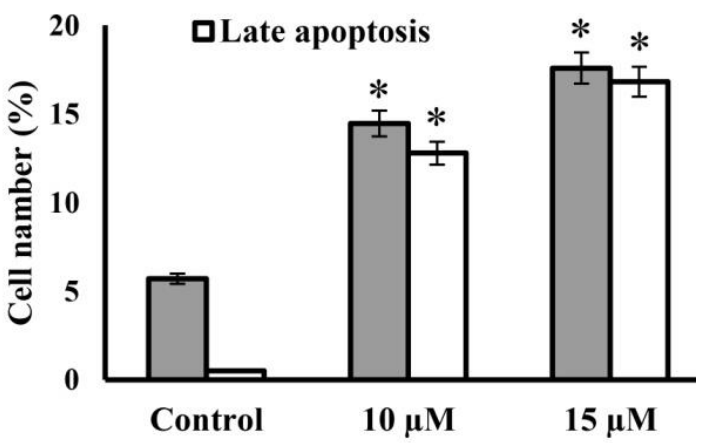

Figure 7. Apoptotic effects of compounds $3 \mathbf{c}$ and $3 \mathbf{f}$ on M-HeLa cells. (A) M-HeLa cells were treated with the indicated compounds at indicated concentrations for $24 \mathrm{~h}$. Apoptotic effects were measured by flow cytometry using annexin V- Alexa Fluor 647 staining protocol. The values are presented as the mean \pm SD $(n=3)$. L-living cells; D—dead cells; Ea-early apoptotic cells; La-late apoptotic cells. (B) Representative histograms for the numbers of cells (\% of total) in the early and late stages of apoptosis for the control and experimental groups. The values are presented as the mean $\pm \operatorname{SD}(n=3)$ : $\left(^{*}\right) p<0.01$ compared to control.

\subsubsection{Effects on the Mitochondrial Membrane Potential $\left(\Delta \Psi_{\mathrm{m}}\right)$}

Earlier, using Multiplex analysis and flow cytometry, we showed that compounds containing benzofuroxan fragments in the structure induce apoptosis, which most likely proceeds via an external pathway through the activation of death receptors located on the surface of cell membranes [40]. In this 
regard, studies were carried out to determine the external or internal mechanism of apoptosis caused by new derivatives of benzofuroxans in M-HeLa cells.

Studies were performed using flow cytometry methods using JC-10 reagent. In normal cells with a high potential of the mitochondrial membrane, the dye JC-10 forms aggregates (J-aggregate) near the mitochondrial membranes. When the membrane potential due to the stimulation of apoptosis falls, JC-10 is evenly distributed in the cell as a monomer (J-monomer). JC-10 units in normal cells have red fluorescence, and JC-10 monomers are green. The ratio between orange-red and green fluorescence can be used to assess the onset of apoptosis, which proceeds along the internal mitochondrial pathway. The experiments carried out confirmed the data obtained earlier.

A serious decrease in $\Delta \Psi_{m}$ was not demonstrated by flow cytometry analysis (Figure 8). The intensity of red fluorescence after treatment of cells with compounds $5 \mathrm{c}$ and $\mathbf{5 g}$ at $\geq$ IC 50 concentrations did not change significantly compared to the control.
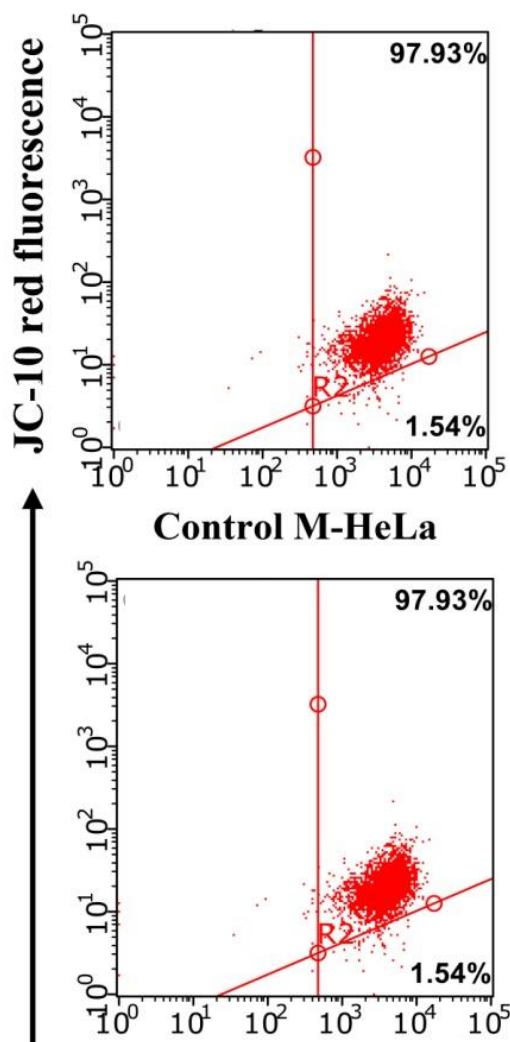

Control M-HeLa

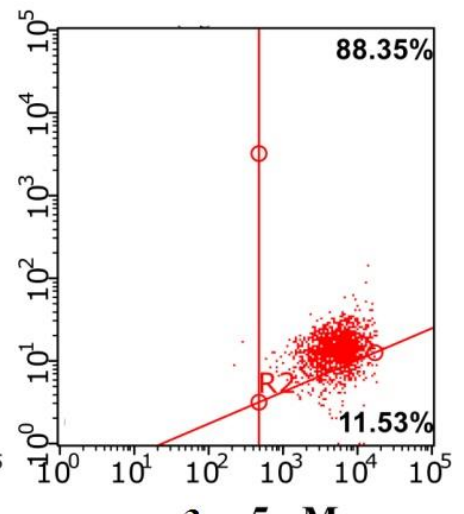

3c $5 \mu \mathrm{M}$

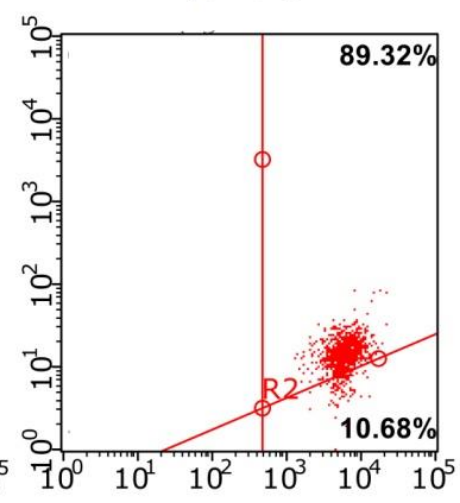

3f $\quad 10 \mu \mathrm{M}$
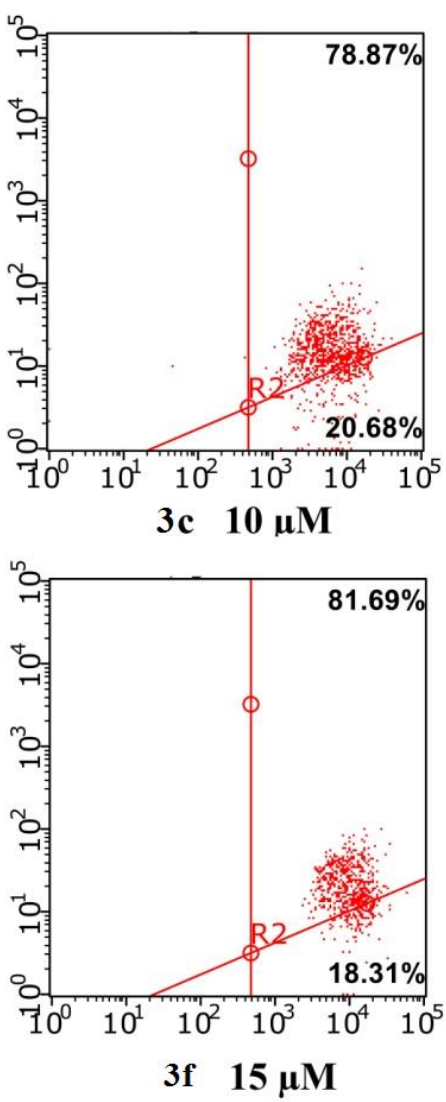

JC-10 green fluorescence

Figure 8. Flow cytometry analysis of M-Hela cells treated with compounds $3 \mathrm{c}$ and $3 \mathrm{f}$ along with the quantification of $\%$ of cells with red aggregates. The values are presented as mean \pm SD.

The results obtained confirm the data that the mechanism of action of benzofuroxan derivatives is not associated with the induction of apoptosis through the internal pathway.

\subsubsection{Cell Cycle Analysis}

Cell cycle analysis by quantification of DNA content is a reliable method to investigate at which phase cell cycle has been arrested, where in Propidium Iodide dye is used which binds in proportion to the amount of DNA present in the cell [58].

The main checkpoint in the regulation of the cell cycle is the transition from the G1-phase to the S-phase. Depending on the amount of nutrients and energy, as well as on external factors, the cell 
decides whether to enter the cell cycle or go into a non-dividing state known as the G0 phase [59]. The results of cell cycle analysis using test compounds $3 \mathrm{c}$ and $\mathbf{3 f}$ against M-HeLa cell line by flow cytometry are shown in Figure 9. The data obtained demonstrate arrest of cells in the G0/G1 phase with a peak after $24 \mathrm{~h}$. The tested compounds caused an increase in the $\%$ arrest in the G0/G1 phase. Compound $3 \mathrm{c}$ by $62.91 \%$ and $70.06 \%$ at 5 and $10 \mu \mathrm{M}$ and $3 \mathrm{f}$ by $65.2 \%$ and $66.8 \%$ at 10 and $15 \mu \mathrm{M}$, respectively, than control cells (34.28\%).
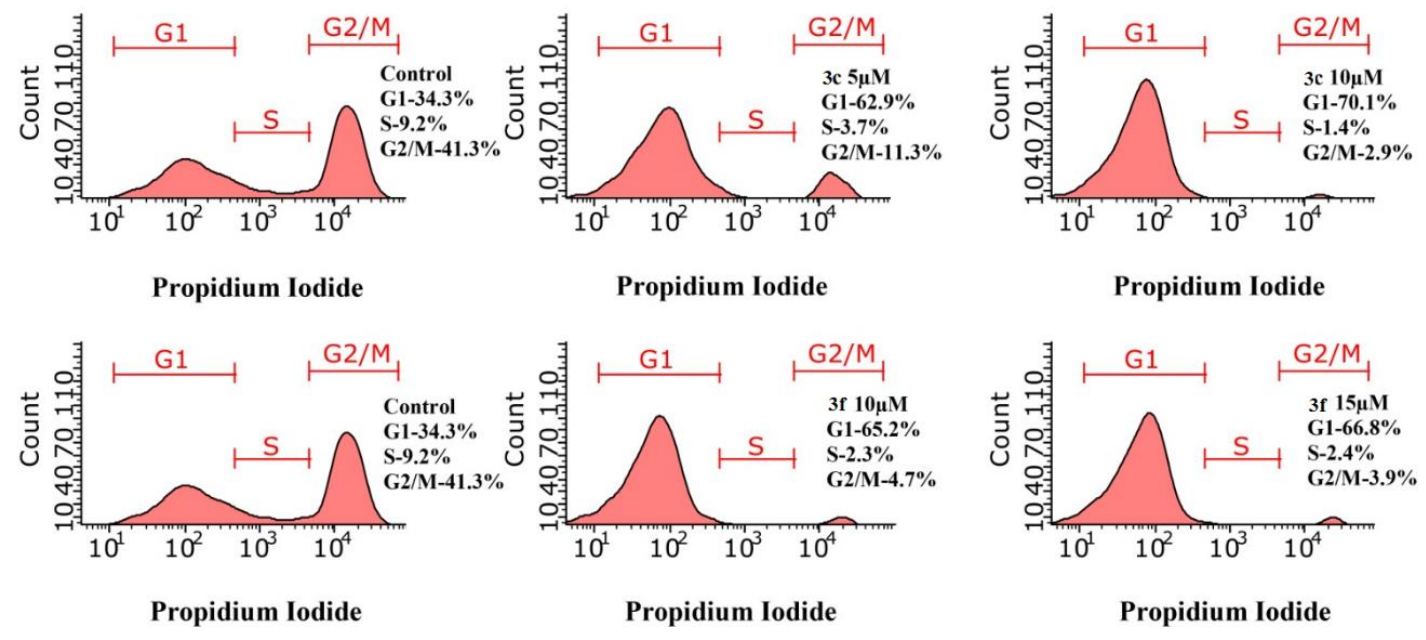

Figure 9. Effect of $3 \mathrm{c}$ and $3 \mathrm{f}$ on cell cycle progression of M-HeLa by flow cytometry.

\section{Materials and Methods}

\subsection{Chemistry}

IR spectra were recorded on a UR-20 spectrometer in the $400-3600 \mathrm{~cm}^{-1}$ range in $\mathrm{KBr} .{ }^{1} \mathrm{H}-\mathrm{NMR}$ spectra were recorded on IR spectra were recorded on a UR-20 spectrometer in the $400-3600 \mathrm{~cm}^{-1}$ range in $\mathrm{KBr}$. The ${ }^{1} \mathrm{H}$ - and ${ }^{13} \mathrm{C}-\mathrm{NMR}$ spectra were recorded on a Bruker AVANCE 400 spectrometer (Bruker BioSpin, Rheinstetten, Germany) operating at $400 \mathrm{MHz}$ (for ${ }^{1} \mathrm{H} \mathrm{NMR}$ ) and $101 \mathrm{MHz}$ (for ${ }^{13} \mathrm{C}$ NMR), Bruker AVANCE 500 (Bruker BioSpin, Rheinstetten, Germany) spectrometer operating at $500 \mathrm{MHz}$ (for ${ }^{1} \mathrm{H}$ NMR) and $126 \mathrm{MHz}$ (for ${ }^{13} \mathrm{C}$ NMR) and Bruker Avance 600 spectrometer (Bruker BioSpin, Rheinstetten, Germany) operating at $600 \mathrm{MHz}$ (for ${ }^{1} \mathrm{H} N \mathrm{NR}$ ) and $151 \mathrm{MHz}$ (for ${ }^{13} \mathrm{C}$ NMR). Chemical shifts were measured in $\delta$ (ppm) with reference to the solvent $(\delta=7.27 \mathrm{ppm}$ and $77.00 \mathrm{ppm}$ for $\mathrm{CDCl}_{3}, \delta=2.06 \mathrm{ppm}$ and $28.94 \mathrm{ppm}$ for $\left(\mathrm{CD}_{3}\right)_{2} \mathrm{CO}$ for ${ }^{1} \mathrm{H}$ and ${ }^{13} \mathrm{C}$ NMR, respectively). Elemental analysis was performed on a CHNS-O Elemental Analyser EuroEA3028-HT-OM (EuroVector S.p.A., Milan, Italy). The melting points were determined in glass capillaries on a Stuart SMP 10 instrument.

X-ray crystallography data: Single crystal X-ray diffraction data were collected on a Bruker Kappa Apex II CCD diffractometer using graphite monochromated $\operatorname{MoK} \alpha(0.71073 \AA)$ radiation and $\omega$-scan rotation. Data collection: images were indexed, integrated, and scaled using the APEX2 [60] data reduction package and corrected for absorption using SADABS [61]. The structures 5a-5d were solved by the direct methods and refined using SHELX [62]. Non-hydrogen atoms were refined anisotropically. Hydrogen atoms were calculated on idealized positions and refined as riding atoms. The X-ray analysis was performed on the equipment of Spectral-Analytical Center of FRC Kazan Scientific Center of RAS.

CCDC xxx (5a-5d) contain the supplementary crystallographic data for this paper. These data can be obtained free of charge via www.ccdc.cam.ac.uk/conts/retrieving.html (or from the Cambridge Crystallographic Data Centre, 12 Union Road, Cambridge CB2 1EZ, UK; fax: (+44) 1223-336-033; or deposit@ccdc.cam.uk).

Quantum-chemical computations. All quantum-chemical computations were carried out with the use of Gaussian 16 suite of programs [63]. Calculations were performed with Becke's three 
parameter hybrid exchange functional [64] and the gradient-corrected nonlocal correlation functional of Lee et al. [65] (B3LYP) in combination with standard 6-31G* basis set [66-68]. For all compounds, geometry optimization of structures was performed without symmetry constraints. To ensure the calculated structures of reagents and products were indeed minima, vibrational analyses were performed using the same methods and were proved by all positive eigenvalues of Hessian matrix. The transition states were confirmed by the presence of one negative eigenvalue in the Hessian matrix of the second derivatives. All calculations were performed for a singlet surface and the solutions found were tested for stability against perturbations imposed on the wave function using the Stable procedure.

The following compounds were prepared following the literature procedures indicated: 4,6-dichloro-5-nitrobenzofuroxan 1 [69], 6-chloro-4-((3-hydroxyphenyl)amino)-5-nitrobenzofuroxan 3f [40], 4-(butylamino)-6-chloro-5-nitrobenzofuroxan 5a, 4-(benzyl(methyl)amino)-6-chloro-5-nitrobenzofuroxan $5 \mathbf{f}$ and 6-chloro-5-nitro-4-(pyrrolidin-1-yl)benzofuroxan 5g [70].

Reaction between 4,6-dichloro-5-nitrobenzofuroxan 1 and amines. To a solution of 4,6-dichloro-5-nitrobenzofuroxan $\mathbf{1}(0.0008 \mathrm{~mol})$ in $5 \mathrm{~mL}$ of $\mathrm{CHCl}_{3}$ or DMSO at room temperature was added a solution of amine $3(0.0016 \mathrm{~mol})$ in $5 \mathrm{~mL}$ of $\mathrm{CHCl}_{3}$ or DMSO. The reaction was carried out at room temperature and under magnetic stirring, and the conversion was monitored through TLC analysis (eluent: toluene/ethyl acetate, 2:/1). After $2-4 \mathrm{~h}$ the crude mixture was precipitated in hexane $(10 \mathrm{~mL})$ from $\mathrm{CHCl}_{3}$ or water from DMSO, the obtained solid was filtered off, washed with cold water $(100 \mathrm{~mL})$ and dried under vacuum $(0.06 \mathrm{~mm} \mathrm{Hg})$ at $40^{\circ} \mathrm{C}$ temperature to constant weight. Crude product was purified by column chromatography (eluent: toluene/ethylacetate, 2/1) and recrystallized from chloroform/hexane (3/1) to give target compound.

6-chloro-4-((4-fluorophenyl)amino)-5-nitrobenzofuroxan (3a). Purpule powder, yield 88\%. M.p.: 166-168 ${ }^{\circ} \mathrm{C}$. IR $\left(v, \mathrm{~cm}^{-1}\right): 1206(\mathrm{CF}), 1368\left(\mathrm{NO}_{2}\right.$ symm), $1558\left(\mathrm{NO}_{2}\right.$ asymm), 1619 (furoxan ring), $3069\left(\mathrm{C}^{7} \mathrm{H}\right), 3441(\mathrm{NH}) .{ }^{1} \mathrm{H}$ NMR $\left(400 \mathrm{MHz}, \mathrm{CDCl}_{3}\right) \delta 8.60(\mathrm{~s}, 1 \mathrm{H}), 7.25(\mathrm{~d}, J=4.5 \mathrm{~Hz}, 1 \mathrm{H}), 7.11(\mathrm{~m}$, $J=8.3 \mathrm{~Hz}, 3 \mathrm{H}), 6.89(\mathrm{~s}, 1 \mathrm{H}) .{ }^{13} \mathrm{C}\{1 \mathrm{H}\} \mathrm{NMR}\left(151 \mathrm{MHz}\right.$, acetone- $\left.\mathrm{d}_{6}\right) \delta 161.14(\mathrm{~d}, J=244.2 \mathrm{~Hz}), 147.47$, $134.99,132.53,131.87,127.33,126.85(\mathrm{~d}, J=8.6 \mathrm{~Hz}), 115.50(\mathrm{~d}, J=23.1 \mathrm{~Hz}), 113.49,101.91$. Anal. calcd $(\%)$ for $\mathrm{C}_{12} \mathrm{H}_{6} \mathrm{ClFN}_{4} \mathrm{O}_{4}$ : C 44.39; $\mathrm{H} 1.86 ; \mathrm{Cl} 10.92 ; \mathrm{N}$ 17.26. Found: $\mathrm{C} 44.41 ; \mathrm{H} 1.78 ; \mathrm{Cl} 10.88 ; \mathrm{N}$ 17.34.

Crystal data: $\mathrm{C}_{12} \mathrm{H}_{6} \mathrm{ClFN}_{4} \mathrm{O}_{4}(M=324.66 \mathrm{~g} / \mathrm{mol})$ : monoclinic, space group $P 2{ }_{1} / c$ (no. 14), $a=9.2825(7), b=19.3395(14), c=7.2702(4) \AA, \beta=110.295(3)^{\circ}, V=1224.11(15) \AA^{3}, Z=4, T=173(2) \mathrm{K}$, $\mathrm{F}(000) 656, \mu(\mathrm{MoK} \alpha)=0.353 \mathrm{~mm}^{-1}, D_{\text {calc }}=1.762 \mathrm{~g} / \mathrm{cm}^{3}, 10,745$ reflections measured $\left(2.1^{\circ} \leq \theta \leq 27.0^{\circ}\right)$, 2670 independent $\left(R_{\text {int }}=0.043\right)$ which were used in all calculations, 199 parameters. The final $R_{1}$ was $0.0382(I>2 \sigma(I))$ and $w R_{2}$ was 0.1349 (all data), GOOF 0.94 , largest diff. peak and hole 0.35 and -0.49 e. $\mathrm{A}^{3}$.

6-chloro-4-((4-chlorophenyl)amino)-5-nitrobenzofuroxan (3b). Red powder, yield 80\%. M.p.: 134-135 ${ }^{\circ} \mathrm{C}$. IR $\left(v, \mathrm{~cm}^{-1}\right): 640(\mathrm{CCl}), 1360\left(\mathrm{NO}_{2}\right.$ symm), $1559\left(\mathrm{NO}_{2}\right.$ asymm), 1618 (furoxan ring), $3098\left(\mathrm{C}^{7} \mathrm{H}\right), 3444(\mathrm{NH}) .{ }^{1} \mathrm{H}$ NMR $\left(500 \mathrm{MHz}\right.$, acetone- $\left.\mathrm{d}_{6}\right) \delta 9.15(\mathrm{~s}, 1 \mathrm{H}), 7.39(\mathrm{~m}, 4 \mathrm{H}), 7.21(\mathrm{~s}, 1 \mathrm{H})$. ${ }^{13} \mathrm{C}$ NMR $\left(126 \mathrm{MHz}\right.$, acetone- $\left.\mathrm{d}_{6}\right) \delta 147.49,137.93,133.81,130.94,130.88,128.80,127.04,125.46,113.56$, 102.88. Anal. calcd (\%) for $\mathrm{C}_{12} \mathrm{H}_{6} \mathrm{Cl}_{2} \mathrm{~N}_{4} \mathrm{O}_{4}$ : C 42.25; $\mathrm{H} 1.77 ; \mathrm{Cl} 20.79 ; \mathrm{N} 16.43$. Found: $\mathrm{C} 42.32 ; \mathrm{H} 1.81$; $\mathrm{Cl} 20.72 ; \mathrm{N} 16.39$.

Crystal data: $\mathrm{C}_{12} \mathrm{H}_{6} \mathrm{Cl}_{2} \mathrm{~N}_{4} \mathrm{O}_{4}(M=341.11 \mathrm{~g} / \mathrm{mol})$ : monoclinic, space group $P 21 / c$ (no. 14$)$ ), $a=9.4235(6), b=19.9626(11), c=7.2938(4) \AA, \beta=108.572(2)^{\circ}, V=1300.64(13) \AA^{3}, Z=4, T=173(2) \mathrm{K}$, $\mathrm{F}(000) 688, \mu(\mathrm{MoK} \alpha)=0.525 \mathrm{~mm}^{-1}, D_{\text {calc }}=1.742 \mathrm{~g} / \mathrm{cm}^{3}, 11,863$ reflections measured $\left(2.0^{\circ} \leq \theta \leq 27.5^{\circ}\right)$, 2987 independent $\left(R_{\text {int }}=0.042\right)$ which were used in all calculations, 199 parameters. The final $R_{1}$ was $0.0388(I>2 \sigma(I))$ and $w R_{2}$ was 0.1416 (all data), GOOF 0.95 , largest diff. peak and hole 0.41 and -0.44 e. $\mathrm{A}^{3}$.

4-((4-bromophenyl)amino)-6-chloro-5-nitrobenzofuroxan (3c). Dark red powder, yield 77\%. M.p.: 178-179 ${ }^{\circ} \mathrm{C}$. IR $\left(v, \mathrm{~cm}^{-1}\right): 683(\mathrm{CBr}), 1360\left(\mathrm{NO}_{2}\right.$ symm), $1563\left(\mathrm{NO}_{2}\right.$ asymm), 1621 (furoxan ring), $3094\left(\mathrm{C}^{7} \mathrm{H}\right), 3382(\mathrm{NH}) .{ }^{1} \mathrm{H}$ NMR $\left(400 \mathrm{MHz}\right.$, acetone- $\left.\mathrm{d}_{6}\right) \delta 9.14(\mathrm{~s}, 1 \mathrm{H}), 7.53(\mathrm{~d}, J=8.6 \mathrm{~Hz}, 2 \mathrm{H})$, $7.32(\mathrm{~d}, J=8.5 \mathrm{~Hz}, 2 \mathrm{H}), 7.22(\mathrm{~s}, 1 \mathrm{H}) .{ }^{13} \mathrm{C}\{1 \mathrm{H}\} \mathrm{NMR}\left(101 \mathrm{MHz}\right.$, acetone-d $\left.\mathrm{d}_{6}\right) \delta 147.48,138.46,134.03$, 
131.80, 130.69, 127.01, 125.64, 118.64, 113.58, 103.03. Anal. calcd (\%) for $\mathrm{C}_{12} \mathrm{H}_{6} \mathrm{BrClN}_{4} \mathrm{O}_{4}$ : C 37.38; $\mathrm{H}$ 1.57; $\mathrm{Br} 20.72 ; \mathrm{Cl} 9.20 ; \mathrm{N}$ 14.53. Found: $\mathrm{C} 37.45 ; \mathrm{H}$ 1.64; $\mathrm{Br} 20.75 ; \mathrm{Cl} 9.34 ; \mathrm{N} 14.62$.

Crystal data: $\mathrm{C}_{12} \mathrm{H}_{6} \mathrm{BrClN}_{4} \mathrm{O}_{4}(M=385.56 \mathrm{~g} / \mathrm{mol})$ : orthorhombic, space group Pbca (no. 61), $a=6.9497(5), b=13.513(1), c=28.0560(19) \AA, V=2634.8(3) \AA^{3}, Z=8, T=100(2) \mathrm{K}, \mathrm{F}(000) 1520$, $\mu(\mathrm{MoK} \alpha)=3.348 \mathrm{~mm}^{-1}, D_{\text {calc }}=1.944 \mathrm{~g} / \mathrm{cm}^{3}, 18,129$ reflections measured $\left(3.3^{\circ} \leq \theta \leq 29.0^{\circ}\right)$, 3507 independent $\left(R_{\text {int }}=0.052\right)$ which were used in all calculations, 199 parameters. The final $R_{1}$ was $0.0297(I>2 \sigma(I))$ and $w R_{2}$ was 0.1152 (all data), GOOF 0.83 , largest diff. peak and hole 0.65 and -0.66 e. $\mathrm{A}^{3}$.

6-chloro-4-((4-cyanophenyl)amino)-5-nitrobenzofuroxan (3d). Compound 3d was prepared as described above for other compounds using DMSO as solvent and heating $70{ }^{\circ} \mathrm{C}$. The reaction mixture was stirred under heating for $2 \mathrm{~h}$. Brown powder, yield $53 \%$. M.p.: $160-161^{\circ} \mathrm{C}$. IR $\left(v, \mathrm{~cm}^{-1}\right)$ : $1360\left(\mathrm{NO}_{2}\right.$ symm), $1554\left(\mathrm{NO}_{2}\right.$ asymm), 1619 (furoxan ring), $2227(\mathrm{CN}), 3089\left(\mathrm{C}^{7} \mathrm{H}\right), 3390(\mathrm{NH}) .{ }^{1} \mathrm{H} \mathrm{NMR}$ $\left(400 \mathrm{MHz}\right.$, acetone- $\left.\mathrm{d}_{6}\right) \delta 9.20(\mathrm{~s}, 1 \mathrm{H}), 7.73(\mathrm{~d}, J=8.3 \mathrm{~Hz}, 2 \mathrm{H}), 7.51(\mathrm{~s}, 1 \mathrm{H}), 7.46(\mathrm{~d}, J=7.9 \mathrm{~Hz}, 2 \mathrm{H})$. ${ }^{13} \mathrm{C}\{1 \mathrm{H}\}$ NMR $\left(101 \mathrm{MHz}\right.$, acetone- $\left.\mathrm{d}_{6}\right) \delta 147.63,144.33,132.97,128.27,126.12,121.57,118.39,113.88$, 109.98, 107.19, 106.45. Anal. calcd (\%) for $\mathrm{C}_{13} \mathrm{H}_{6} \mathrm{ClN}_{5} \mathrm{O}_{4}$ : C 47.08; $\mathrm{H} 1.82 ; \mathrm{Cl} 10.69 ; \mathrm{N}$ 21.12. Found: C 47.15; $\mathrm{H} 1.78 ; \mathrm{Cl} 10.59 ; \mathrm{N} 21.16$.

Crystal data: $\mathrm{C}_{13} \mathrm{H}_{6} \mathrm{ClN}_{5} \mathrm{O}_{4}(M=331.68 \mathrm{~g} / \mathrm{mol})$ : monoclinic, space group $P 2_{1} / \mathrm{c}$ (no. 14), $a=8.5796(7), b=23.2320(17), c=7.2254(6) \AA, \beta=111.777(4)^{\circ}, V=1337.40(19) \AA^{3}, Z=4, T=100(2) \mathrm{K}$, $\mathrm{F}(000) 672, \mu(\mathrm{MoK} \alpha)=0.317 \mathrm{~mm}^{-1}, D_{\text {calc }}=1.647 \mathrm{~g} / \mathrm{cm}^{3}, 16,075$ reflections measured $\left(1.8^{\circ} \leq \theta \leq 27.0^{\circ}\right)$, 2905 independent $\left(R_{\text {int }}=0.041\right)$ which were used in all calculations, 208 parameters. The final $R_{1}$ was $0.0330(I>2 \sigma(I))$ and $w R_{2}$ was 0.1228 (all data), GOOF 0.91, largest diff. peak and hole 0.37 and -0.30 e. $\mathrm{A}^{3}$.

6-chloro-4-((2-methoxyphenyl)amino)-5-nitrobenzofuroxan (3e) Red powder, yield 79\%, m.p.: 133-134 ${ }^{\circ} \mathrm{C}$. IR $\left(v, \mathrm{~cm}^{-1}\right): 1308\left(\mathrm{NO}_{2}\right.$ symm), $1562\left(\mathrm{NO}_{2}\right.$ asymm), 1628 (furoxan ring), $3086\left(\mathrm{C}^{7} \mathrm{H}\right)$, $3331(\mathrm{NH}) .{ }^{1} \mathrm{H}$ NMR $\left(400 \mathrm{MHz}, \mathrm{CDCl}_{3}\right) \delta 8.61(\mathrm{~s}, 1 \mathrm{H}), 7.33(\mathrm{t}, J=7.9 \mathrm{~Hz}, 1 \mathrm{H}), 7.24(\mathrm{~d}, J=7.7 \mathrm{~Hz}$, $1 \mathrm{H}), 6.98(\mathrm{~m}, J=7.7 \mathrm{~Hz}, 2 \mathrm{H}), 6.85(\mathrm{~s}, 1 \mathrm{H}), 3.82(\mathrm{~s}, 3 \mathrm{H}) .{ }^{13} \mathrm{C}\{1 \mathrm{H}\} \mathrm{NMR}\left(101 \mathrm{MHz}, \mathrm{CDCl}_{3}\right) \delta 153.39$, $146.43,133.98,131.10,128.75,128.66,126.36,125.54,120.60,112.93,111.46,101.87,55.74$. Anal. calcd (\%) for $\mathrm{C}_{13} \mathrm{H}_{9} \mathrm{ClN}_{4} \mathrm{O}_{5}$ : C 46.38; $\mathrm{H} 2.69 ; \mathrm{Cl} 10.53 ; \mathrm{N}$ 16.64. Found: C 46.34; H 2.62; Cl 10.51; N 16.69.

6-chloro-4-(hexylamino)-5-nitrobenzofuroxan (5b). Dark red powder, yield 90\%, m.p.: $95-96{ }^{\circ} \mathrm{C}$. IR $\left(v, \mathrm{~cm}^{-1}\right): 689(\mathrm{CCl}), 1332\left(\mathrm{NO}_{2}\right.$ symm), $1535\left(\mathrm{NO}_{2}\right.$ asymm), 1615 (furoxan ring), $3080\left(\mathrm{C}^{7} \mathrm{H}\right)$, $3430(\mathrm{NH}) .{ }^{1} \mathrm{H}$ NMR $\left(400 \mathrm{MHz}, \mathrm{CDCl}_{3}\right), \delta 8.36(\mathrm{~s}, 1 \mathrm{H}), 6.61(\mathrm{~s}, 1 \mathrm{H}), 4.06(\mathrm{dd}, J=13.3,7.0 \mathrm{~Hz}, 2 \mathrm{H})$, $1.84-1.69(\mathrm{~m}, 2 \mathrm{H}), 1.45(\mathrm{dd}, J=14.5,7.2 \mathrm{~Hz}, 2 \mathrm{H}), 1.36(\mathrm{dt}, J=7.3,4.8 \mathrm{~Hz}, 4 \mathrm{H}), 0.91(\mathrm{dd}, J=9.7,4.4 \mathrm{~Hz}$, $3 \mathrm{H}) .{ }^{13} \mathrm{C}\{1 \mathrm{H}\} \mathrm{NMR}\left(101 \mathrm{MHz}, \mathrm{CDCl}_{3}\right), \delta 147.36,138.39,129.96,126.98,112.66,99.41,77.35,77.03,76.71$, $47.45,31.25,30.13,26.27,22.43,13.89$. Anal. calcd (\%) for $\mathrm{C}_{12} \mathrm{H}_{15} \mathrm{ClN}_{4} \mathrm{O}_{4}$ : C 45.80; $\mathrm{H} 4.80 ; \mathrm{Cl} 11.26$; N 17.80. Found: C 45.84; H 4.82; Cl 11.25; N 17.76.

6-chloro-4-((3-morpholinopropyl)amino)-5-nitrobenzofuroxan (5c). Orange powder, yield 87\%, m.p.: $110-111{ }^{\circ} \mathrm{C}$. IR $\left(v, \mathrm{~cm}^{-1}\right): 1335\left(\mathrm{NO}_{2}\right.$ symm), $1536\left(\mathrm{NO}_{2}\right.$ asymm), 1620 (furoxan ring), $3087\left(\mathrm{C}^{7} \mathrm{H}\right)$, $3435(\mathrm{NH}) .{ }^{1} \mathrm{H}$ NMR $\left(600 \mathrm{MHz}\right.$, acetone- $\left.\mathrm{d}_{6}\right) \delta 8.82(\mathrm{~s}, 1 \mathrm{H}), 6.76(\mathrm{~s}, 1 \mathrm{H}), 4.12(\mathrm{~m}, 2 \mathrm{H}), 3.72-3.62(\mathrm{~m}, 4 \mathrm{H})$, 2.59-2.53 (m, 2H), $2.45(\mathrm{~m}, 4 \mathrm{H}), 2.01-1.93(\mathrm{~m}, 2 \mathrm{H}) .{ }^{13} \mathrm{C}\{1 \mathrm{H}\}$ NMR (151 MHz, acetone- $\left.\mathrm{d}_{6}\right) \delta 148.15$, $136.88,128.53,127.90,113.30,98.14,66.10,57.38,53.97,46.67,24.98$. Anal. calcd (\%) for $\mathrm{C}_{13} \mathrm{H}_{16} \mathrm{ClN}_{5} \mathrm{O}_{5}$ : C 43.64; H 4.51; Cl 9.91; N 19.58. Found: C 43.56; H 4.54; Cl 9.93; N 20.01.

6-chloro-4-(cyclohexylamino)-5-nitrobenzofuroxan (5d). Orange powder, yield $94 \%$, m.p.: $113-115^{\circ} \mathrm{C}$. IR $\left(v, \mathrm{~cm}^{-1}\right): 1330\left(\mathrm{NO}_{2}\right.$ symm), $1530\left(\mathrm{NO}_{2}\right.$ asymm), 1620 (furoxan ring), $3082\left(\mathrm{C}^{7} \mathrm{H}\right)$, $3436(\mathrm{NH}) .{ }^{1} \mathrm{H}$ NMR $\left(600 \mathrm{MHz}\right.$, acetone- $\left.\mathrm{d}_{6}\right) \delta 8.13-8.02(\mathrm{~s}, 1 \mathrm{H}), 6.80(\mathrm{~s}, 1 \mathrm{H}), 2.80-2.85(\mathrm{~m}, 1 \mathrm{H}), 2.16(\mathrm{~d}$, $J=9.3 \mathrm{~Hz}, 2 \mathrm{H}), 1.83-1.77(\mathrm{~m}, 2 \mathrm{H}), 1.59(\mathrm{dd}, J=21.7,9.6 \mathrm{~Hz}, 2 \mathrm{H}), 1.46(\mathrm{dd}, J=25.2,12.1 \mathrm{~Hz}, 2 \mathrm{H}) .{ }^{13} \mathrm{C}\{1 \mathrm{H}\}$ NMR (151 MHz, acetone- $\left.\mathrm{d}_{6}\right) \delta 147.71,136.75,128.70,127.61,113.38,99.09,55.43,33.25,24.96,24.46$. Anal. calcd (\%) for $\mathrm{C}_{12} \mathrm{H}_{13} \mathrm{ClN}_{4} \mathrm{O}_{4}$ : C 46.09; $\mathrm{H} 4.19 ; \mathrm{Cl} 11.34 ; \mathrm{N}$ 17.92. Found: $\mathrm{C} 46.05 ; \mathrm{H} 4.23 ; \mathrm{Cl} 11.29$; N 17.96.

6-chloro-4-(morpholinoamino)-5-nitrobenzofuroxan (5e). Purpule powder, yield 42\%, m.p.: 155-156 ${ }^{\circ} \mathrm{C}$. IR $\left(v, \mathrm{~cm}^{-1}\right): 1339\left(\mathrm{NO}_{2}\right.$ symm), $1536\left(\mathrm{NO}_{2}\right.$ asymm), 1624 (furoxan ring), $3077\left(\mathrm{C}^{7} \mathrm{H}\right)$, 
$3425(\mathrm{NH}) .{ }^{1} \mathrm{H}$ NMR $\left(600 \mathrm{MHz}, \mathrm{CDCl}_{3}\right) \delta 6.98(\mathrm{~s}, 1 \mathrm{H}), 3.90-3.86(\mathrm{~m}, 4 \mathrm{H}), 3.62-3.58(\mathrm{~m}, 4 \mathrm{H}) .{ }^{13} \mathrm{C} \mathrm{NMR}$ $\{1 \mathrm{H}\}\left(151 \mathrm{MHz}, \mathrm{CDCl}_{3}\right) \delta 148.91,134.86,127.78,113.44,106.82,103.38,66.65,50.22$. Anal. calcd (\%) for $\mathrm{C}_{10} \mathrm{H}_{10} \mathrm{ClN}_{5} \mathrm{O}_{5}$ : C 38.05; H 3.19; $\mathrm{Cl} 11.23 ; \mathrm{N} 22.19$. Found: C 38.07; H 3.22; Cl 11.25; N 22.17.

The mixture of 7-((4-isopropylphenyl)amino)-4,6-dinitrobenzofuroxan (6A) and 6-((4-isopropylphenyl)amino)-5,7-dinitrobenzofuroxan (6B).

To a solution of benzofuroxan $(0.0008 \mathrm{~mol})$ in chloroform $(5 \mathrm{~mL})$ at room temperature was added amine $(0.0016 \mathrm{~mol})$. The reaction mixture was stirred for $2 \mathrm{~h}$. The solvent was evaporated in vacuo to give the crude product. Recrystallization from system chloroform/hexane (3:1) gave pure compound 7-(4-isopropylphenylamino)-4,6-dinitrobenzofuroxan 6. Purpule powder, yield $42 \%$, m.p.: $110-11{ }^{\circ} \mathrm{C}$. IR $\left(v, \mathrm{~cm}^{-1}\right)$ : $1336\left(\mathrm{NO}_{2}\right.$ symm), $1558\left(\mathrm{NO}_{2}\right.$ asymm), 1625 (furoxan ring), $3385(\mathrm{NH})$. Exists in solution as two tautomers. Major tautomer: ${ }^{1} \mathrm{H}$ NMR $(600 \mathrm{MHz}$, Acetone) $\delta 11.24(\mathrm{~s}, 1 \mathrm{H})$, $9.13(\mathrm{~s}, 1 \mathrm{H}), 7.35(\mathrm{dd}, J=23.0,8.5 \mathrm{~Hz}, 4 \mathrm{H}), 3.00-295(\mathrm{~m}, 1 \mathrm{H}), 1.27-1.26(\mathrm{~d}, J=6.9 \mathrm{~Hz}, 6 \mathrm{H}) .{ }^{13} \mathrm{C}$ NMR $\left(151 \mathrm{MHz}\right.$, acetone- $\left.\mathrm{d}_{6}\right) \delta 148.58,146.89,138.52,136.94,131.88,127.32,127.06,126.06,122.04,111.44$, 33.60, 23.23. Minor tautomer: ${ }^{1} \mathrm{H}$ NMR $(600 \mathrm{MHz}$, Acetone) $\delta 11.74(\mathrm{~s}, 1 \mathrm{H}), 8.89(\mathrm{~s}, 1 \mathrm{H}), 7.49(\mathrm{~d}$, $J=8.2,4 \mathrm{H}), 2.78-2.80(\mathrm{~m}, 1 \mathrm{H}), 1.30-1.29(\mathrm{~d}, J=7.0 \mathrm{~Hz}, 6 \mathrm{H}) .{ }^{13} \mathrm{C}$ NMR $\left(151 \mathrm{MHz}\right.$, acetone- $\left.\mathrm{d}_{6}\right) \delta 146.64$, $148.15,141.85,135.73,126.98,126.95,125.43,124.63,124.95,106.46,33.68,23.33$. Anal. calcd (\%) for $\mathrm{C}_{15} \mathrm{H}_{13} \mathrm{~N}_{5} \mathrm{O}_{6}$ : C 50.14; H 3.65; N 19.49. Found: C 50.19; H 3.67; N 19.45.

\subsection{Biological Studies}

\subsubsection{Bacterial Biofilm Formation Inhibitory Activity}

Materials and methods. Bacterial strain and cultivation conditions. For detection of biofilms formation strain Vibrio aquamarinus DSM 26054 was used. The strain forms biofilms, making this microorganism useful for studying biofilms.

V. aquamarinus DSM 26054 was cultivated for $24 \mathrm{~h}$ in LB medium [71], supplemented with 3\% $\mathrm{NaCl}$ in the Innova 40R shaker incubator (New Brunswick Scientific, Enfield, CT, USA) at $25^{\circ} \mathrm{C}$ and $200 \mathrm{rpm}$.

Chemicals. All of the chemicals used were of analytical grade. Crystal violet was obtained from Sigma-Aldrich (St. Louis, MO, USA). Azithromycin was obtained from Farmstandart (Moscow, Russia). Test solutions were prepared in deionized water immediately before the tests.

The test compounds were dissolved in DMSO to the concentration of $1 \times 10^{-2} \mathrm{M}$. Then they were diluted with ethanol. The control solutions were analogous dilutions of DMSO in ethanol. The tested compounds were also compared with the standard antibiotic Azithromycin. Azithromycin was dissolved in DMSO to the concentration of $5 \times 10^{-3} \mathrm{M}$. Then it was diluted with deionized water.

Test system for evaluation of biofilms production. To quantify the formation of biofilms the crystal violet assay with some modifications was used [72]. The necessary concentrations of the test compounds were prepared as described above.

Then, the suspensions of the daily culture of V. aquamarinus DSM 26054 was diluted with LB medium supplemented with $3 \% \mathrm{NaCl}$ to the density of $10^{8}$ cells $/ \mathrm{mL}$.

The resulting suspension $(190 \mu \mathrm{L})$ was added to the wells of a polystyrene microplate (Nuova Aptaca, Canelly, Regione Monforte, Italy). To some of the wells, $10 \mu \mathrm{L}$ of the test substances at various concentrations were added. Since solvents used could also influence the biofilm formation, $10 \mu \mathrm{L}$ of the appropriate solvent were added to the other part of the wells at same dilutions (control). Six replicates were done for each treatment and control. The microplate was covered with a lid and wrapped with a Parafilm (Bemis Company, Inc., Neenah, WI, USA).

After incubation at $25^{\circ} \mathrm{C}$ for $72 \mathrm{~h}$, biofilms were stained. The contents in the wells were removed by means of a dispenser. The wells were then carefully washed three times with $250 \mu \mathrm{L}$ of sterile saline. The microplates were shaken to remove all non-adherent bacteria. Biofilms were fixed with $200 \mu \mathrm{L}$ of $96 \%$ ethanol for $15 \mathrm{~min}$. After the microplates had dried in air, $200 \mu \mathrm{L}$ of $0.5 \%$ crystal violet were introduced into the wells. After $10 \mathrm{~min}$, the dye was removed. The excess dye was removed by 
washing with water three times. After the microplates were air-dried, the dye in the wells bound to biofilms was dissolved with $200 \mu \mathrm{L}$ of $96 \%$ ethanol. The extraction level (absorption) of crystal violet by ethanol was measured after $60 \mathrm{~min}$ at a wavelength of $570 \mathrm{~nm}$ using a FLUOstar Omega microplate reader (BMG Labtech, Ortenberg, Germany) in optical density units (OD570). The intensity of biofilm formation directly corresponds to the intensity of staining of the contents of the wells with the dye. Biofilm formation was determined by the difference between the mean OD readings obtained in the presence of compounds and the control.

Each experiment was performed in triplicate. The values were expressed as mean + SD. Student's T-test was used to compare these values. Differences were considered statistically significant at $p<0.05$.

\subsubsection{Fungistatic Activity of Benzofuroxans}

Fungistatic activity of the tested compounds was assessed in vitro using agar growth medium poison technique [73-75]. The target compounds as well as widely used fungicides benzimidazole and carbendazim [54-56] were dissolved to $10 \mathrm{mM}$ concentration in $20 \%$ Tween 20 . The obtained solutions were added 1:9 $v / v$ (giving $1 \mathrm{mM}$-concentrations of the target compounds) to potato-sucrose agar (PSA) [76] at $60^{\circ} \mathrm{C}$, mixed thoroughly and transferred to Petri dishes. For the control variants, PSA was supplemented with 20\% Tween 20 (9:1). Fungistatic effect was tested against two isolates of Microdochium nivale causing snow mold disease of winter cereals (rye) from the culture collection of FRC Kazan Scientific Center of RAS. According to DNA sequence of ITS2 region, the isolates were genetically distinct (differed in ITS2 region sequence), but both belonged to the same species Microdochium nivale (paper under review). The center of each solidified medium was inoculated upside-down with 5-mm diameter mycelial plug cut from the periphery of 10-day-old cultures. The tested dishes were incubated at $20^{\circ} \mathrm{C}$. The percentage growth inhibition was calculated using Abbott's formula (1):

$$
\% \text { Inhibition }=[(\mathrm{A}-\mathrm{B}) \div \mathrm{A}] \times 100
$$

where ' $\mathrm{A}$ ' is mycelia growth in the control conditions and ' $\mathrm{B}$ ' is mycelia growth in the treatment conditions. The assay was performed at least in triplicate. Linear growth of each colony was determined during 6 days.

\subsubsection{Cytotoxicity Assay}

Cytotoxic effects of the test compounds on human cancer and normal cells were estimated by means of the multifunctional Cytell Cell Imaging system (GE Health Care Life Science, Uppsala, Sweden) using the Cell Viability Bio App which precisely counts the number of cells and evaluates their viability from fluorescence intensity [40]. Two fluorescent dyes that selectively penetrate the cell membranes and fluoresce at different wavelengths were used in the experiments. DAPI is able to penetrate intact membranes of living cells and colors nuclei in blue and Propidium iodide dye penetrates only dead cells with damaged membranes, staining them in yellow. $\mathrm{IC}_{50}$ was calculated using an online tool: MLA “Quest Graph ${ }^{\mathrm{TM}} \mathrm{IC}_{50}$ Calculator." AAT Bioquest, Inc, 25 July 2019, https://www.aatbio.com/tools/ic50-calculator. DAPI and propidium iodide were purchased from Sigma. The M-Hela clone 11 human, epithelioid cervical carcinoma, strain of Hela, clone of M-Hela; human breast adenocarcinoma cells (MCF-7); PANC-1-human pancreatic cancer cell line, glioblastoma cell line (T98G) from the Type Culture Collection of the Institute of Cytology (Russian Academy of Sciences) and Chang liver cell line (Human liver cells) from N. F. Gamaleya Research Center of Epidemiology and Microbiology were used in the experiments. The cells were cultured in a standard Eagle's nutrient medium manufactured at the Chumakov Institute of Poliomyelitis and Virus Encephalitis (PanEco company, Moscow, Russia) and supplemented with 10\% fetal calf serum and $1 \%$ nonessential amino acids. The cells were plated into a 96-well plate (Eppendorf, Hamburg, Germany) at a concentration of $10^{5}$ cells $/ \mathrm{mL}, 150 \mu \mathrm{L}$ of medium per well, and cultured in a $\mathrm{CO}_{2}$ incubator at $37^{\circ} \mathrm{C}$. Twenty-four hours after seeding the cells into wells, the compound under study 
was added at a preset dilution, $150 \mu \mathrm{L}$ to each well. The dilutions of the compounds were prepared immediately in nutrient media; $5 \%$ DMSO that does not induce inhibition of cells at this concentration was added for better solubility. The experiments were repeated three times. Intact cells cultured in parallel with experimental cells were used as a control.

\subsubsection{Flow Cytometry Assay}

Cell Culture. M-HeLa cells at $10^{6}$ cells/ well in a final volume of $2 \mathrm{~mL}$ were seeded into 6-well plates. After $24 \mathrm{~h}$ of incubation, various concentrations of compounds $3 \mathrm{c}$ and $3 \mathrm{f}$ were added to wells.

Cell Apoptosis Analysis. The cells were harvested at $2000 \mathrm{rpm}$ for $5 \mathrm{~min}$ and, then, washed twice with ice-cold PBS, followed by resuspension in binding buffer $100 \mu \mathrm{L}$. Next, the samples were incubated with $0.35 \mu \mathrm{L}$ of annexin V-Alexa Fluor 647 and $0.1 \mu \mathrm{L}$ of propidium iodide for $40 \mathrm{~min}$ at room temperature in the dark. Finally, the cells were analyzed by flow cytometry (Guava easyCyte, MERCK, Kenilworth, NJ, USA). The experiments were repeated three times.

\subsubsection{Mitochondrial Membrane Potential}

The cells were harvested at $2000 \mathrm{rpm}$ for $5 \mathrm{~min}$ and, then, washed twice with ice-cold PBS, followed by resuspension in JC-10 $(10 \mu \mathrm{g} / \mathrm{mL})$ and incubation at $37^{\circ} \mathrm{C}$ for $10 \mathrm{~min}$. After the cells were rinsed three times and suspended in PBS, the JC-10 fluorescence was observed by flow cytometry.

\subsubsection{Cell Cycle Analysis}

The DNA content and cell-cycle distribution after genistein treatment were estimated by flow cytometry. Cell seeding, drug treatment and ethanol fixation were similar to cell proliferation assay. After washing with PBS, genistein and daidzein-treated and -fixed cells were suspended in $150 \mu \mathrm{L}$ of PBS, then $0.5 \mathrm{~mL}$ phosphate-citrate buffer $(0.05 \mathrm{M}, \mathrm{pH}=4.0)$ was added and the suspension was incubated at room temperature for $5 \mathrm{~min}$ to facilitate the extraction of low molecular weight DNA. Following centrifugation the cells were resuspended in $150 \mu \mathrm{L}$ DNA staining solution $(20 \mu \mathrm{g} / \mathrm{mL}$ propidium iodide, $200 \mu \mathrm{g} / \mathrm{mL}$ DNase (RNase-free), and $0.1 \%$ Triton X-100) and incubated in the $\mathrm{CO}_{2}$ incubator $\left(37^{\circ} \mathrm{C}\right.$ for $\left.30 \mathrm{~min}\right)$. Cell cycle distribution was determined by fluorescence-activated cell sorting analysis of propidium iodide-stained ethanol-fixed cells using a Guava EasyCyte (Guava easyCyte, MERCK, Kenilworth, NJ, USA) [77].

\subsubsection{Statistical Analysis}

$\mathrm{IC}_{50}$ was calculated using an online tool: MLA “Quest Graph ${ }^{\mathrm{TM}} \mathrm{IC}_{50}$ Calculator”. AAT Bioquest, Inc, 25 July 2019, https:/www.aatbio.com/tools/ic50-calculator.

The cytometric results were analyzed by the Cytell Cell Imaging multifunctional system using the Cell Viability BioApp and Apoptosis BioApp application. The data in tables and graphs are given as the mean \pm standard error.

\section{Conclusions}

Series of novel 4-aminobenzofuroxans was synthesized through nucleophilic aromatic substitution reaction of 4,6-dichloro-5-nitrobenzofuroxan. The regioselectivity of chlorine atom substitution only in the 4 position was first proved using the quantum chemistry calculations. The substitution of this chlorine atom is favored by the greater stability of the reaction product. Additionally, the formation of the 4-substituted product proceeds with the lower activation barrier. So, both thermodynamic and kinetic factors make this pathway preferable. The biological activity of the obtained compounds was also evaluated. Thus, some of the obtained compounds inhibit effectively bacterial biofilm growth. Moreover, the importance of the introduction of aromatic amines fragments was shown in comparison with derivatives containing fragments of aliphatic amines in the study of anti-fungal and anti-cancer activities. The effect of some benzofuroxan derivatives is likely to be more universal against 
different varieties of $M$. nivale fungi compared with benzimidazole and carbendazim. Additionally, 4-aminofuroxans possessing aniline moiety exhibit a high selectivity towards MCF-7 and M-HeLa tumor cell lines. At the same time, they are significantly less toxic towards normal liver cells compared to Doxorubicin and Tamoxifen. Thus, these compounds are promising candidates for further development both as anti-cancer and anti-microbial agents.

Supplementary Materials: The following are available online at http://www.mdpi.com/1422-0067/21/21/ 8292/s1, Table S1, Figures S1-S3—quantum chemical modeling, Figures S4-S14-Anti-biofilm activity data, Figures S15-S34—copies of NMR spectra of all synthesized compounds.

Author Contributions: E.C.-writing-original draft preparation, supervision (chemistry), A.G. (Almir Gazizov)—writing-review and editing, M.S.—supervision (anti-biofilm activity), N.A. (Nurgali Akylbekov)—investigation (chemistry), I.S., A.G. (Anastasiya Gildebrant), S.K., M.K.—investigation (anti-biofilm activity), A.B.-project administration, N.A. (Nurbol Appazov) - investigation (chemistry), funding acquisition, A.V.- supervision (in vitro anti-cancer studies), A.S., S.G.-investigation (in vitro anti-cancer studies), A.K., T.G.—software, investigation (quantum-chemical computations), A.D.-investigation (X-ray study), O.G., V.G.- investigation (fungistatic activity). All authors have read and agreed to the published version of the manuscript.

Funding: Quantum-chemical computations and the study of in vitro anti-cancer activity were funded by financial support from the government assignment for the FRC Kazan Scientific Center of RAS. The synthesis and fungistatic activity assay was supported by the Ministry of Science and Higher Education of the Russian Federation (grant No. 075-15-2019-1881). The study of anti-biofilm activity was funded the Ministry of Science and Higher Education of the Russian Federation in the framework of State assignment No. 0852-2020-0029 in the field of scientific activity, and President of Russian Federation (grant No. NSh-2511.2020.11). N. Akylbekov and N. Appazov are grateful for the financial support to the Committee of Science of the Ministry of Education and Science of the Republic of Kazakhstan, project No. AP05134356.

Acknowledgments: The authors are grateful to the Assigned Spectral-Analytical Center of FRC Kazan Scientific Center of RAS for technical assistance in research. The X-ray measurements were performed using shared experimental facilities supported by IGIC RAS state assignment.

Conflicts of Interest: The authors declare no conflict of interest.

\section{References}

1. Mfuh, A.M.; Larionov, O.V. Heterocyclic N-Oxides-An emerging class of therapeutic agents. Curr. Med. Chem. 2015, 22, 2819-2857. [CrossRef] [PubMed]

2. Li, D.; Wu, P.; Sun, N.; Lu, Y.-J.; Wong, W.-L.; Fang, Z.; Zhang, K. The diversity of Heterocyclic N-oxide molecules: Highlights on their potential in organic synthesis, catalysis and drug applications. Curr. Org. Chem. 2019, 23, 616-627. [CrossRef]

3. Chugunova, E.A.; Burilov, A.R. Novel structural hybrids on the base of benzofuroxans and furoxans. Mini-review. Curr. Top. Med. Chem. 2017, 17, 986-1005. [CrossRef] [PubMed]

4. Cerecetto, H.; Gonzalez, M. Benzofuroxan and Furoxan. Chemistry and Biology. In Bioactive Heterocycles IV. Topics in Heterocyclic Chemistry; Khan, M.T.H., Ed.; Springer: Berlin/Heidelberg, Germany, 2007; Volume 10, pp. 265-308. ISBN 978-3-540-73404-8.

5. Chugunova, E.A.; Sazykina, M.A.; Gibadullina, E.M.; Burilov, A.R.; Sazykin, I.S.; Chistyakov, V.A.; Timasheva, R.E.; Krivolapov, D.B.; Goumont, R. Synthesis, genotoxicity and uv-protective activity of new benzofuroxans substituted by aromatic amines. Lett. Drug Des. Discov. 2013, 10, 145-154. [CrossRef]

6. Micheletti, G.; Boga, C.; Pafundi, M.; Pollicino, S.; Zanna, N. New electron-donor and -acceptor architectures from benzofurazans and sym-triaminobenzenes: Intermediates, products and an unusual nitro group shift. Org. Biomol. Chem. 2016, 14, 768-776. [CrossRef] [PubMed]

7. Micheletti, G.; Delpivo, C.; Baccolini, G. A green synthesis of glycoluril derivatives in aqueous solution with recycle of the waste. Green Chem. Lett. Rev. 2013, 6, 135-139. [CrossRef]

8. Boga, C.; Cino, S.; Micheletti, G.; Padovan, D.; Prati, L.; Mazzanti, A.; Zanna, N. New azo-decorated N-pyrrolidinylthiazoles: Synthesis, properties and an unexpected remote substituent effect transmission. Org. Biomol. Chem. 2016, 14, 7061-7068. [CrossRef] [PubMed]

9. Smolobochkin, A.V.; Gazizov, A.S.; Burilov, A.R.; Pudovik, M.A.; Sinyashin, O.G. Ring-opening reactions of nitrogen heterocycles. Russ. Chem. Rev. 2019, 88, 1104-1127. [CrossRef] 
10. Khmel'nitskii, L.I.; Novikov, S.S.; Godovikova, T.I. In Chemistry of Furoxans: Reactions and Application; Nauka: Moscow, Russia, 1996.

11. Wang, L.; Li, C.; Zhang, Y.; Qiao, C.; Ye, Y. Synthesis and biological evaluation of benzofuroxan derivatives as Fungicides against Phytopathogenic Fungi. J. Agric. Food Chem. 2013, 61, 8632-8640. [CrossRef] [PubMed]

12. Chugunova, E.; Mukhamatdinova, R.; Sazykina, M.; Dobrynin, A.; Sazykin, I.; Karpenko, A.; Mirina, E.; Zhuravleva, M.; Gavrilov, N.; Karchava, S.; et al. Synthesis of new "Hybrid" compounds based on Benzofuroxans and Aminoalkylnaphthalimides. Chem. Biol. Drug Des. 2016, 87, 626-634. [CrossRef]

13. Chugunova, E.; Akylbekov, N.; Shakirova, L.; Dobrynin, A.; Syakaev, V.; Latypov, S.; Bukharov, S.; Burilov, A. Synthesis of hybrids of benzofuroxan and N-, S-containing sterically hindered phenols derivatives. Tautomerism. Tetrahedron 2016, 72, 6415-6420. [CrossRef]

14. de Carvalho, P.S.; Maróstica, M.; Gambero, A.; Pedrazzoli, J. Synthesis and pharmacological characterization of a novel nitric oxide-releasing diclofenac derivative containing a benzofuroxan moiety. Eur. J. Med. Chem. 2010, 45, 2489-2493. [CrossRef] [PubMed]

15. Boga, C.; Micheletti, G.; Cino, S.; Fazzini, S.; Forlani, L.; Zanna, N.; Spinelli, D. C-C coupling between trinitrothiophenes and triaminobenzenes: Zwitterionic intermediates and new all-conjugated structures. Org. Biomol. Chem. 2016, 14, 4267-4275. [CrossRef]

16. Del Vecchio, E.; Boga, C.; Forlani, L.; Tozzi, S.; Micheletti, G.; Cino, S. Ring closure of azo compounds to 1,2-annulated benzimidazole derivatives and further evidence of reversibility of the azo-coupling reaction. J. Org. Chem. 2015, 80, 2216-2222. [CrossRef] [PubMed]

17. Radomski, J.L. The primary aromatic amines: Their biological properties and structure-activity relationships. Annu. Rev. Pharmacol. Toxicol. 1979, 19, 129-157. [CrossRef]

18. Ali, M.I.; Liton, M.A.K. Cytotoxicity, 2D- and 3D-QSAR study of some halogen containing hydroxy and amino substituted aromatic compounds. World J. Org. Chem. 2015, 3, 16-26. [CrossRef]

19. Chugunova, E.A.; Voloshina, A.D.; Mukhamatdinova, R.E.; Serkov, I.V.; Proshin, A.N.; Gibadullina, E.M.; Burilov, A.R.; Kulik, N.V.; Zobov, V.V.; Krivolapov, D.B.; et al. The study of the biological activity of amino-substituted benzofuroxans. Lett. Drug Des. Discov. 2014, 11, 502-512. [CrossRef]

20. Chugunova, E.A.; Akylbekov, N.I.; Voloshina, A.D.; Kulik, N.V.; Zobov, V.V.; Babaev, V.M.; Gavrilov, N.V.; Burilov, A.R. Synthesis and investigation of antimicrobial activity of compounds derived from benzo[c][1,2,5]oxadiazole-1-oxides and phenolates. Synth. Commun. 2016, 46, 1560-1565. [CrossRef]

21. Chugunova, E.A.; Akylbekov, N.I.; Mahrous, E.M.; Voloshina, A.D.; Kulik, N.V.; Zobov, V.V.; Strelnik, A.G.; Gerasimova, T.P.; Dobrynin, A.B.; Burilov, A.R. Synthesis and study of antimicrobial activity of quaternary ammonium benzofuroxan salts. Mon. für Chem. Chem. Mon. 2018, 149, 119-126. [CrossRef]

22. Gibadullina, E.M.; Chugunova, E.A.; Mironova, E.V.; Krivolapov, D.B.; Burilov, A.R.; Yusupova, L.M.; Pudovik, M.A. Reaction of 4,6-dichloro-5-nitrobenzofuroxan with aromatic amines and nitrogen-containing heterocycles. Chem. Heterocycl. Compd. 2012, 48, 1228-1234. [CrossRef]

23. Galkina, I.V.; Tudriy, E.V.; Bakhtiyarova, Y.V.; Usupova, L.M.; Shulaeva, M.P.; Pozdeev, O.K.; Egorova, S.N.; Galkin, V.I. Synthesis and antimicrobial activity of Bis-4,6-sulfonamidated 5,7-Dinitrobenzofuroxans. J. Chem. 2014, 2014, 367351. [CrossRef]

24. Prima, D.O.; Vorontsova, E.V.; Makarov, A.G.; Makarov, A.Y.; Bagryanskaya, I.Y.; Mikhailovskaya, T.F.; Slizhov, Y.G.; Zibarev, A.V. Halogenated (F, Cl) 1,3-benzodiazoles, 1,2,3-benzotriazoles, 2,1,3-benzothia(selena)diazoles and 1,4-benzodiazines inducing Hep2 cell apoptosis. Mendeleev Commun. 2017, 27, 439-442. [CrossRef]

25. Prima, D.O.; Makarov, A.G.; Bagryanskaya, I.Y.; Kolesnikov, A.E.; Zargarova, L.V.; Baev, D.S.; Eliseeva, T.F.; Politanskaya, L.V.; Makarov, A.Y.; Slizhov, Y.G.; et al. Fluorine-containing n-6 and angular and linear n-6-n' $\left(\mathrm{n}, \mathrm{n}^{\prime}=5,6,7\right)$ Diaza-Heterocyclic scaffolds assembled on benzene core in Unified Way. ChemistrySelect 2019, 4, 2383-2386. [CrossRef]

26. Heaton, A.; Hill, M.; Drakesmith, F. Polyhalogenonitrobenzenes and derived compounds Part 5. Improved preparations of 1,2,3,4-tetrafluoro-5,6-dinitrobenzene and 3,4,5,6-tetrafluoro-1,2-phenylenediamine, and the use of the latter for the synthesis of tetrafluorobenzheterocycles. J. Fluor. Chem. 1997, 81, 133-138. [CrossRef]

27. Liljenberg, M.; Brinck, T.; Herschend, B.; Rein, T.; Tomasi, S.; Svensson, M. Predicting regioselectivity in nucleophilic aromatic substitution. J. Org. Chem. 2012, 77, 3262-3269. [CrossRef] 
28. Nova, A.; Mas-Ballesté, R.; Ujaque, G.; González-Duarte, P.; Lledós, A. Aromatic C-F activation by complexes containing the $\{\mathrm{Pt} 2 \mathrm{~S} 2\}$ core via nucleophilic substitution: A combined experimental and theoretical study. Dalton Trans. 2009, 5980. [CrossRef]

29. Liljenberg, M.; Brinck, T.; Herschend, B.; Rein, T.; Rockwell, G.; Svensson, M. A pragmatic procedure for predicting regioselectivity in nucleophilic substitution of aromatic fluorides. Tetrahedron Lett. 2011, 52, 3150-3153. [CrossRef]

30. Muir, M.; Baker, J. A simple calculational model for predicting the site for nucleophilic substitution in aromatic perfluorocarbons. J. Fluor. Chem. 2005, 126, 727-738. [CrossRef]

31. Baker, J.; Muir, M. The Meisenheimer model for predicting the principal site for nucleophilic substitution in aromatic perfluorocarbons-Generalization to include ring-nitrogen atoms and non-fluorine ring substituents. Can. J. Chem. 2010, 88, 588-597. [CrossRef]

32. Singh, A.; Goel, N. Regioselective nucleophilic aromatic substitution reactions of 5,7-dinitroquinazoline-4-one and 5,7-dinitroquinazoline-4-thione with methylamine: A mechanistic consideration. New J. Chem. 2015, 39, 4351-4358. [CrossRef]

33. Liljenberg, M.; Brinck, T.; Rein, T.; Svensson, M. Utilizing the $\sigma$-complex stability for quantifying reactivity in nucleophilic substitution of aromatic fluorides. Beilstein J. Org. Chem. 2013, 9, 791-799. [CrossRef]

34. Lage, O.M.; Ramos, M.C.; Calisto, R.; Almeida, E.; Vasconcelos, V.; Vicente, F. Current screening methodologies in drug discovery for selected human diseases. Mar. Drugs 2018, 16, 279. [CrossRef]

35. Hassan, S.T.; Berchová, K.; Šudomová, M. Antimicrobial, antiparasitic and anticancer properties of Hibiscus sabdariffa (L.) and its phytochemicals: In vitro and in vivo studies. Ces. A Slov. Farm. 2016, 65, 10-14.

36. Vijayakumar, S.; Malaikozhundan, B.; Saravanakumar, K.; Durán-Lara, E.F.; Wang, M.H.; Vaseeharan, B. Garlic clove extract assisted silver nanoparticle-Antibacterial, antibiofilm, antihelminthic, anti-inflammatory, anticancer and ecotoxicity assessment. J. Photochem. Photobiol. B Biol. 2019, 98, 111558. [CrossRef] [PubMed]

37. Samanta, A.; Podder, S.; Kumarasamy, M.; Ghosh, C.K.; Lahiri, D.; Roy, P.; Bhattacharjee, S.; Ghosh, J.; Mukhopadhyay, A.K. Au nanoparticle-decorated aragonite microdumbbells for enhanced antibacterial and anticancer activities. Mater. Sci. Eng. C 2019, 103, 109734. [CrossRef] [PubMed]

38. Bilal, M.; Zhao, Y.; Rasheed, T.; Ahmed, I.; Hassan, S.T.S.; Nawaz, M.Z.; Iqbal, H.M.N. Biogenic nanoparticle-chitosan conjugates with antimicrobial, antibiofilm, and anticancer potentialities: Development and characterization. Int. J. Environ. Res. Public Health 2019, 16, 598. [CrossRef]

39. Borowiecki, P.; Wińska, P.; Bretner, M.; Gizińska, M.; Koronkiewicz, M.; Staniszewska, M. Synthesis of novel proxyphylline derivatives with dual Anti-Candida albicans and anticancer activity. Eur. J. Med. Chem. 2018, 150, 307-333. [CrossRef]

40. Smolobochkin, A.; Gazizov, A.; Sazykina, M.; Akylbekov, N.; Chugunova, E.; Sazykin, I.; Gildebrant, A.; Voronina, J.; Burilov, A.; Karchava, S.; et al. Synthesis of novel 2-(Het)arylpyrrolidine derivatives and evaluation of their anticancer and anti-biofilm activity. Molecules 2019, 24, 3086. [CrossRef]

41. Smolobochkin, A.V.; Muravyeva, E.A.; Vagapova, L.I.; Knyazeva, I.R.; Voronina, J.K.; Burilov, A.R.; Pudovik, M.A.; Gildebrant, A.V.; Sazykin, I.S.; Sazykina, M.A.; et al. Synthesis and evaluation of water-soluble 2-Aryl-1-Sulfonylpyrrolidine derivatives as bacterial biofilm formation inhibitors. Chem. Biodivers. 2019, 16, e1800490. [CrossRef]

42. Smolobochkin, A.V.; Rizbayeva, T.S.; Gazizov, A.S.; Voronina, J.K.; Dobrynin, A.B.; Gildebrant, A.V.; Strelnik, A.G.; Sazykin, I.S.; Burilov, A.R.; Pudovik, M.A.; et al. Acid-catalyzed intramolecular imination/nucleophilic trapping of 4-Aminobutanal derivatives: One-pot access to 2-(Pyrazolyl)pyrrolidines. Eur. J. Org. Chem. 2019, 2019, 5709-5719. [CrossRef]

43. Calabrese, E.J.; Baldwin, L.A. The frequency of U-shaped dose responses in the toxicological literature. Toxicol. Sci. 2001, 62, 330-338. [CrossRef] [PubMed]

44. Kendig, E.L.; Le, H.H.; Belcher, S.M. Defining hormesis: Evaluation of a complex concentration response phenomenon. Int. J. Toxicol. 2010, 29, 235-246. [CrossRef] [PubMed]

45. Owen, S.C.; Doak, A.K.; Ganesh, A.N.; Nedyalkova, L.; McLaughlin, C.K.; Shoichet, B.K.; Shoichet, M.S. Colloidal drug formulations can explain "bell-shaped" concentration-response curves. ACS Chem. Biol. 2014, 9, 777-784. [CrossRef]

46. Matsumoto, N.; Hsiang, T. Snow Mold: The Battle under Snow between Fungal Pathogens and Their Plant Hosts; Springer: Berlin/Heidelberg, Germany, 2016. 
47. Nakajima, T.; Abe, J. Environmental factors affecting expression of resistance to pink snow mold caused by Microdochium nivale in winter wheat. Can. J. Bot. 1996, 74, 1783-1788. [CrossRef]

48. Iriki, N.; Gaudet, D.A.; Tronsmo, A.M.; Matsumoto, N.; Yoshida, M.; Hsiang, T.; Okuyama, H.; Nakajima, T. Low temperature diseases caused by Microdochium nivale. In Low Temperature Plant Microbe Interactions Under Snow; Iriki, N., Gaudet, D.A., Tronsmo, A.M., Matsumoto, N., Yoshida, M., Nishimune, A., Eds.; The Hokkaido National Agricultural Experiment Station: Sapporo, Japan, 2001; pp. 75-86.

49. Pronczuk, M.; Madej, L.; Kolasinska, I. Research for resistance to Microdochium nivale among inbred lines of rye. Plant Breed. Seed Sci. 2003, 48, 83-86.

50. Mahuku, G.S.; Hsiang, T.; Yang, L. Genetic diversity of Microdochium nivale isolates from turfgrass. Mycol. Res. 1998, 102, 559-567. [CrossRef]

51. Abdelhalim, M.; Brurberg, M.B.; Hofgaard, I.S.; Rognli, O.A.; Tronsmo, A.M. Pathogenicity, host specificity and genetic diversity in Norwegian isolates of Microdochium nivale and Microdochium majus. Eur. J. Plant Pathol. 2020, 156, 885-895. [CrossRef]

52. Hsiang, T.; Matsumoto, N.; Millett, S.M. Biology and management of typhula snow molds of turfgrass. Plant Dis. 1999, 83, 788-798. [CrossRef] [PubMed]

53. Walker, A.S.; Auclair, C.; Gredt, M.; Leroux, P. First occurrence of resistance to strobilurin fungicides in Microdochium nivale and Microdochium majus from French naturally infected wheat grains. Pest Manag. Sci. 2009, 65, 906-915. [CrossRef]

54. Chen, Y.; Zhou, M.G. Characterization of Fusarium graminearum isolates resistant to both carbendazim and a new fungicide JS399-19. Phytopathology 2009, 99, 441-446. [CrossRef]

55. Lucas, J.A.; Hawkins, N.J.; Fraaije, B.A. Chapter Two-The Evolution of Fungicide Resistance. In Advances in Applied Microbiology; Gadd, G.M., Sariaslani, S., Eds.; Elsevier: Amsterdam, The Netherlands, 2015; Volume 90, pp. 29-92. [CrossRef]

56. Sevastos, A.; Kalampokis, I.F.; Panagiotopoulou, A.; Pelecanou, M.; Aliferis, K.A. Implication of Fusarium graminearum primary metabolism in its resistance to benzimidazole fungicides as revealed by $1 \mathrm{H}$ NMR metabolomics. Pestic. Biochem. Physiol. 2018, 148, 50-61. [CrossRef]

57. Salah Ayoup, M.; Wahby, Y.; Abdel-Hamid, H.; Ramadan, E.S.; Teleb, M.; Abu-Serie, M.M.; Noby, A. Design, synthesis and biological evaluation of novel $\alpha$-acyloxy carboxamides via Passerini reaction as caspase 3/7 activators. Eur. J. Med. Chem. 2019, 168. [CrossRef] [PubMed]

58. Garifullin, B.F.; Strobykina, I.Y.; Khabibulina, L.R.; Sapunova, A.S.; Voloshina, A.D.; Sharipova, R.R.; Khairutdinov, B.I.; Zuev, Y.F.; Kataev, V.E. Synthesis and cytotoxicity of the conjugates of diterpenoid isosteviol and N-acetyl-D-glucosamine. Nat. Prod. Res. 2019. [CrossRef] [PubMed]

59. Bell, S.P.; Dutta, A. DNA replication in eukaryotic cells. Annu. Rev. Biochem. 2002, 71, 333-374. [CrossRef]

60. APEX2 (Version 2.1), SAINTPlus. Data Reduction and Correction Program (Version 7.31A, Bruker Advansed X-ray Solutions; BrukerAXS Inc.: Madison, WI, USA, 2006.

61. Sheldrick, G.M. SADABS, Program for Empirical X-ray Absorption Correction; Bruker-Nonius: Billerica, MA, USA, 1990.

62. Sheldrick, G.M. Crystal structure refinement with SHELXL. Acta Crystallogr. Sect. C 2015, 71, 3-8. [CrossRef] [PubMed]

63. Frisch, M.J.; Trucks, G.W.; Schlegel, H.B.; Scuseria, G.E.; Robb, M.A.; Cheeseman, J.R.; Scalmani, G.; Barone, V.; Petersson, G.A.; Nakatsuji, H.; et al. Gaussian 16, Revision B.01; Gaussian Inc.: Wallingford, CT, USA, 2016.

64. Becke, A.D. Density functional thermochemistry III the role of exact exchange. J. Chem. Phys. 1993, 98, 5648-5652. [CrossRef]

65. Lee, C.; Yang, W.; Parr, R.G. Development of the Colle-Salvetti correlation-energy formula into a functional of the electron density. Phys. Rev. B 1988, 37, 785-789. [CrossRef]

66. Hehre, W.J.; Ditchfield, R.; Pople, J.A. Self-Consistent molecular orbital methods. XII. Further extensions of Gaussian-Type basis sets for use in molecular orbital studies of organic molecules. J. Chem. Phys. 1972, 56, 2257-2261. [CrossRef]

67. Ditchfield, R.; Hehre, W.J.; Pople, J.A. Self-consistent molecular-orbital methods. IX. An extended gaussian-type basis for molecular-orbital studies of organic molecules. J. Chem. Phys. 1971, 54, 724. [CrossRef]

68. Petersson, G.A.; Bennett, A.; Tensfeldt, T.G.; Al-Laham, M.A.; Shirley, W.A.; Mantzaris, J. A complete basis set model chemistry. I. The total energies of closed-shell atoms and hydrides of the first-row elements. J. Chem. Phys. 1988, 89, 2193-2218. [CrossRef] 
69. Yusupova, L.M.; Molodykh, Z.V.; Buzykin, B.I.; Falyakhov, I.F.; Anisimova, N.N.; Sharnin, G.P.; Bulidorov, V.V.; Sviridov, S.I.; Levinson, F.S. 4- or 6-Nitro-5,7-Dichlorobenzofuroxan Having Fungicidal Activity. RU Patent 2,032,678, 10 April 1995.

70. Chugunova, E.; Frenna, V.; Consiglio, G.; Micheletti, G.; Boga, C.; Akylbekov, N.; Burilov, A.; Spinelli, D. On the nucleophilic reactivity of 4,6-dichloro-5-nitrobenzofuroxan with aliphatic and aromatic amines: Selective nucleophilic substitution. J. Org. Chem. 2020. [CrossRef]

71. Maniatis, T.; Fritsch, E.F.F.; Sambrook, J.; Fritsch, E.F.F.; Maniatis, T. Molecular Cloning—A Laboratory Manual; Cold Spring Harbor Laboratory: New York, NY, USA, 1982; ISBN 0-87969-136-0.

72. Stepanović, S.; Vuković, D.; Dakić, I.; Savić, B.; Švabić-Vlahović, M. A modified microtiter-plate test for quantification of staphylococcal biofilm formation. J. Microbiol. Methods 2000, 40, 175-179. [CrossRef]

73. Puškárová, A.; Bučková, M.; Kraková, L.; Pangallo, D.; Kozics, K. The antibacterial and antifungal activity of six essential oils and their cyto/genotoxicity to human HEL 12469 cells. Sci. Rep. 2017, 7, 8211. [CrossRef] [PubMed]

74. Walczak, P.; Pannek, J.; Boratyński, F.; Janik-Polanowicz, A.; Olejniczak, T. Synthesis and fungistatic activity of bicyclic lactones and lactams against Botrytis cinerea, Penicillium citrinum, and Aspergillus glaucus. J. Agric. Food Chem. 2014, 62, 8571-8578. [CrossRef] [PubMed]

75. Krzysko-Łupicka, T.; Walkowiak, W.; Białon, M. Comparison of the fungistatic activity of selected essential oils relative to fusarium graminearum isolates. Molecules 2019, 24, 311. [CrossRef]

76. Booth, C. Chapter II fungal culture media. In Methods in Microbiology; Academic Press: New York, NY, USA, 1971; pp. 49-94.

77. Han, J.; Kurita, Y.; Isoda, H. Genistein-induced G2/M cell cycle arrest of human intestinal colon cancer Caco-2 cells is associated with Cyclin B1 and Chk2 down-regulation. Cytotechnology 2013, 65, 973-978. [CrossRef] [PubMed]

Publisher's Note: MDPI stays neutral with regard to jurisdictional claims in published maps and institutional affiliations.

(C) 2020 by the authors. Licensee MDPI, Basel, Switzerland. This article is an open access article distributed under the terms and conditions of the Creative Commons Attribution (CC BY) license (http://creativecommons.org/licenses/by/4.0/). 